Policy Research Working Paper 2867

\title{
Cotton Sector Strategies in West and Central Africa
}

\section{Evolution des filières cotonnieres en Afrique de l'Ouest et du Centre}

\author{
Ousmane Badiane \\ Dhaneshwar Ghura \\ Louis Goreux \\ Paul Masson
}

The World Bank

Africa Technical Families

Rural Development 2

July 2002 
Poilcy Resfarch Wokking Paper 2867

\section{Abstract}

Cotton production is truly a success story in West and Central Africa. The region is now the second largest exporter of lint, after the United States, with a world market share of 15 percent. Despite its strong performance in the past, the sector is characterized by several institutional and structural weaknesses that jeopardize its viability in an era of increasing globalization of the cotton industry. The sector's future performance will also depend on the implications of corton sector policies in major producing countries such as the United States, the European Union, and China. This paper examines how the above factors may affect future growth of the region's corton industry. It also identifies the changes that are required to enable countries in the region to fully exploit the sector's significant growth potential.

\section{Abstrait}

La culture du coton a connu un énorme succìs en Afrique de l'Ouest et du Centre. La région est actuellement deuxième exportateur mondial derrière les Etats Unis, avec une part de marché de 15 pourcent. Malgré la forte performance qu'elle a connu dans le passé, la filière est caractériséc par des déficiences d'ordre institutionnel et structurel qui menacent sa viabilité dans un contexte de mondialisarion croissante de l'industrie cotonnière. L'avenir de la filière est

également menacé par les effets des politiques cotonnic̀res de certains grands producteurs tels que les Etats Unis, l'Union Europécnne, et la Chine. Le présent rapport analyse limpact des facteurs cités ci-dessus sur la performance future de l'industrie cotonnière dans la région. Il identific également les changements qui doivent être effecrués afin de permettre au pays de la sous-région d'exploiter au maximum l'énorme potentiel de croissance qui existe dans la filière.

This paper-a producr of Rural Development 2, Africa Technical Families-is part of a larger effort in the region ro contribute to the debate on development strategies in West and Central Africa. Copies of the paper are available free from the World Bank, $1818 \mathrm{H}$ Street NW, Washington, DC 20433. Please contact Azra Lodi, room J6-269, telephone 202-4734478, fax 202-473-5147, email address alodi(ti) worldbank.org. Policy Research Working Papers are also posted on the Web ar http://econ.worldbank.org. The authors may be contacted at obadiane@iworldbank.org, dghura@limf.org, or pmasson@imf.org. July 2002.

The Policy Research Working Paper Senes disscminates the findings of work in proygress to encourage the exchange of ideas ahout development issues. An objective of the series is to get the findings out quickly. even if the presentations are less than fully polished. The papers carry the names of the authors and should be cted accordingly. The findngs, interpretations. and conclusions expressed in this paper are entively those of the autbors. They do not necessarily represent the vicu of the World Bank, its Executite Directors, or the countries they represent. 


\title{
COTTON SECTOR STRATEGIES
}

\section{IN WEST AND CENTRAL AFRICA}

\author{
By \\ Ousmane Badiane \\ Dhaneshwar Ghura \\ Louis Goreux and \\ Paul Masson ${ }^{*}$
}

July 2002

*) The authors are, respectively, Lead Specialist, Food and Agricultural Policy, Africa Region, World Bank; Deputy Division Chief, Africa Department, International Monetary Fund; Consultant, World Bank; and Senior Advisor, Africa Department, International Monetary Fund. 



\section{EXECUTIVE SUMMARY}

Cotton production has improved rural welfare and contributed to economic growth in the CFA franc Zone countries of West and Central Africa (WCA). Production has increased fourfold in the last two decades, making the region the world's second largest cotton exporter, with a share of world exports of 15 percent. Cotton is the main cash crop and the largest source of export receipts and government revenues in several countries of the region. Cotton cultivation employs more than two million rural households and hence is a key factor for poverty reduction.

In spite of its success in promoting cotton cultivation, the current system of integrated national cotton monopsonies has exhibited weaknesses. In particular, the system relies on (a) the ability of the monopsonies to tax producers and accumulate profits in times of high export prices, and (b) the availability of budgetary support from national governments in times of low international prices. Thus, the recent decline in world market prices would have produced a sharp fall in growers' revenues without the assistance provided by the international donor community to national governments.

For several years, the World Bank and the International Monetary Fund (IMF) have advocated reforms along the following lines:

- allowing free entry and competition at all levels of the cotton sector, including crossborder trade in seed cotton;

- developing private-sector-based mechanisms to ensure effective input credit recovery linked to the marketing of cotton;

- adopting pricing mechanisms that allow producer prices to reflect changes in world prices;

- developing effective market-based mechanisms to reduce price risks;

- building the technical and commercial capacities of producer associations to facilitate their participation in voluntary contract farming arrangements, input supply, and technical services;

- establishing agribusiness trade associations to allow the private sector to participate effectively in the coordination and financing of sector-wide technical support services; and

- improving the provision of services, especially research, extension, and phytosanitary controls, where governments have an essential role in financing the public goods component.

Experience suggests that the implementation of this reform agenda will take several years to complete. As explained in the text, individual WCA countries are at different stages of progress toward establishing competitive sectors. For the next crop season, the pricing mechanisms adopted should not call into question the objectives of enhanced competition 
and privatization, nor roll back the reforms that have already been implemented. The prospects for achieving sustained poverty reduction in West and Central Africa would be greatly improved if the above-mentioned reforms were implemented.

At the same time, subsidies to cotton farmers in major cotton producing countries increase artificially the supply in international markets and depress export prices for WCA countries. Downward pressures on export prices have been exacerbated by generous (and in the case of the United States, rapidly increasing) subsidies for cotton production in the United States, China, and the European Union. Removal of these subsidies would benefit WCA countries, and allow them to better exploit their comparative advantage in cotton production for growth and poverty reduction. 


\section{A. INTRODUCTION}

The recent fall in the world price of cotton has produced a serious loss of export revenues and fiscal receipts for some of the poorest African countries, at a time when many of these countries are reforming their cotton sectors to make them more competitive and less state dependent. The cotton sectors in the CFA franc zone countries in West and Central Africa (WCA) ${ }^{1}$ have until recently been characterized by a single parastatal company that provided inputs and other services to farmers, and purchased all of their cotton harvest. This system, while it produced substantial increases in cotton production, typically paid prices to farmers that were lower than those in cotton-producing countries with more competitive arrangements. For several WCA countries, cotton is the largest source of export receipts; cotton is often the only cash crop, and the cotton sector is key to rural poverty reduction. Consequently, the Bretton Woods institutions have advocated reforms that should lead to a less centralized system and allow for free entry into ginning and competition for the purchase of seed cotton. This would raise the level of efficiency and reduce both costs and margins in the ginning sector, thereby creating the room for higher farmer shares in export prices. ${ }^{2}$

This paper considers (a) the factors behind the decline in world prices and their implications for long term growth of the cotton sectors in WCA countries, and (b) the reforms that need to take place to increase the competitiveness of the cotton sectors in these countries and enable them to cope with similar trends in international markets in the future. In particular, further progress needs to be made toward greater competition and free entry in all major sub-sectors of the industry. The paper also discusses the consequences of the large and (in the case of the United States) rapidly increasing subsidies to cotton producers by developed as well as developing countries in Europe and Asia. While it stresses the need for African countries to put in place systems that provide growers with a larger share of the world price, and at the same time make the sector less vulnerable to fluctuations in export markets and therefore less reliant on government involvement, the paper also underlines the importance of significant reduction or removal by other countries-in particular the United States, China, and countries of the European Union-of their support to cotton farmers. Removal of the subsidies in these countries would eliminate incentives to overproduction, which displace African exports now and constrain further growth of the cotton sector and hence the ability to fight poverty in the WCA countries.

\footnotetext{
${ }^{1}$ The cotton-producing countries considered here are Benin, Burkina Faso, Cameroon, Central African Republic, Chad, Côte d'Ivoire, Mali, Senegal, and Togo. We do not discuss non-CFA countries in West and Central Africa (Ghana, Guinea, Nigeria) --- because their cotton sectors are organized differently --- nor the smaller CFA franc zone producers (Guinea Bissau, Niger).

${ }^{2}$ Given its sectoral expertise, the World Bank has taken the lead in guiding the reform of the cotton sector in WCA. However, IMF programs have also incorporated elements of cottonsector reforms for these countries, when central to their macroeconomic stability.
} 
This paper is not meant to provide an in-depth analysis of the policy and institutional problems or the long-term growth challenge facing the cotton sector in West and Central Africa (which is being done in a separate study by the World Bank Rural Development Team). The objective of this paper is to (a) present the point of view of the IMF and the World Bank with respect to the main global and domestic policy issues surrounding the cotton sector, and (b) provide guidance on reform strategies to the staffs of the two institutions that are dealing with the sector.

\section{B. The Global CONTEXT}

\section{Global Production and Trade Patterns}

The world cotton market is characterized by dispersed production (though mainly in the northern hemisphere) and extensive trade in lint cotton. Though cotton's share in textiles has declined over time in favor of synthetic fibers, cotton remains by far the world's most important fiber, with a share of about 40 percent. Major producers, in declining order of importance, are China, the United States, India, Pakistan, and Uzbekistan. WCA countries together are smaller, but still important, producers, accounting in the latest crop year for about 5 percent of world production (Table 1) and 15 percent of exports.

\section{Global Policies Affecting Cotton Production and Trade}

Most major producers outside of the WCA region have programs aimed at supporting cotton production. In 1998-99 and 1999-2000, such programs were in place in the following eight countries, accounting for an estimated 53 percent of world output: Brazil, China, Egypt, Greece, Mexico, Spain, Turkey and the United States. ${ }^{3}$ For the 1998-99 crop season, the level of assistance offered by governments to the cotton sector in those eight countries amounted to $\$ 5.4$ billion. In the following year, Egypt reduced its price support, but the seven other countries maintained theirs. Over 40 percent of the support was provided by the United States (Table 2). The high levels of subsidy have been a main source of the downward pressure on world prices (Figure 1).

The European Union (EU) provides the most generous assistance to cotton growers --- more than 100 percent of world prices. Moreover, EU subsidies for cotton are exceptionally generous when compared to other crops: three to four times larger per hectare than for maize and oilseeds, and seven to eight times larger than for cereals. However, cotton production (limited to Greece and Spain) is much lower than that in China or the United States. The Common Agricultural Policy's cotton subsidy system was reformed in 1999 to increase penalties for excess production. China provides substantial assistance to cotton farmers

\footnotetext{
${ }^{3}$ See Carlos Valderrama Becerra. 2000. The World Cotton Market: Prices and Distortions. Paper presented at the 10th Australian Cotton Conference, Brisbane, Australia. 17 August, 2000. International Cotton Advisory Committee, Washington, D.C.
} 
Common Agricultural Policy's cotton subsidy system was reformed in 1999 to increase penalties for excess production. China provides substantial assistance to cotton farmers

Table 1. Major Producing Countries: Production and Net Exports of Cotton, 1980/81-2001/02

(In thousands of metric tons)

\begin{tabular}{|c|c|c|c|c|c|c|c|c|}
\hline & $1980 / 81$ & $1985 / 86$ & $1990 / 91$ & $1995 / 96$ & $1998 / 99$ & $1999 / 00$ & $2000 / 01$ & $\frac{2001 / 02}{\text { Proi. }}$ \\
\hline & \multicolumn{8}{|c|}{ Production } \\
\hline China, Peoples Rep. of & 2,703 & 4,142 & 4,513 & 4,774 & 4,513 & 3,837 & 4,425 & 5,123 \\
\hline United States & 2,425 & 2,928 & 3,380 & 3,902 & 3,034 & 3,699 & 3,747 & 4,374 \\
\hline India & 1,323 & 1,967 & 1,991 & 2,886 & 2,774 & 2,655 & 2,376 & 2,572 \\
\hline Pakistan & 715 & 1,218 & 1,640 & 1,788 & 1,373 & 1,875 & 1,788 & 1,744 \\
\hline Uzbekistan & 1,671 & 1,730 & 1,595 & 1,251 & 1,003 & 1,129 & 959 & 1,046 \\
\hline European Union & 676 & 756 & 945 & 1,337 & 1,334 & 1,365 & 1,321 & 1,401 \\
\hline West and Central Africa $1 /$ & 214 & 364 & 536 & 683 & 878 & 848 & 701 & 959 \\
\hline Brazil & 623 & 831 & 701 & 390 & 458 & 676 & 894 & 719 \\
\hline Others & 3,491 & 3,565 & 3,680 & 3,269 & 3,061 & 2,942 & 3,083 & 2,989 \\
\hline \multirow[t]{2}{*}{ World } & 13,841 & 17,501 & 18,981 & 20,280 & 18,428 & 19,026 & 19,294 & 20,928 \\
\hline & \multicolumn{8}{|c|}{ Net Exports } \\
\hline China, Peoples Rep. of & -773 & 610 & -278 & -659 & 70 & 344 & 47 & -65 \\
\hline United States & 1,286 & 420 & 1,698 & 1,584 & 850 & 1,450 & 1,471 & 2,134 \\
\hline India & 119 & 77 & 154 & 105 & -68 & -334 & -327 & -382 \\
\hline Pakistan & 324 & 685 & 295 & 286 & -199 & -13 & 27 & -87 \\
\hline Uzbekistan & 1,448 & 1,487 & 1,173 & 985 & 830 & 893 & 740 & 718 \\
\hline European Union & -715 & $-1,071$ & -827 & -725 & -783 & $-1,021$ & -871 & .923 \\
\hline West and Central Africa 1 / & 185 & 336 & 440 & 600 & 778 & 816 & 689 & 818 \\
\hline Brazil & 6 & 24 & 67 & -363 & -296 & -335 & -82 & -207 \\
\hline
\end{tabular}

Source: International Cotton Advisory Committee.

1/ CFA franc zone only. 
Table 2. Assistance Provided to Major Cotton Producers, 1999/00

\begin{tabular}{|c|c|c|c|}
\hline \multirow[b]{2}{*}{ Country } & \multirow{2}{*}{$\begin{array}{l}\text { Production } \\
\text { Thousand tons }\end{array}$} & \multicolumn{2}{|c|}{ Assistance } \\
\hline & & U.S.\$ Per kilogram & Million U.S. dollars \\
\hline Total & 9,942 & 0.57 & 4,764 \\
\hline United States & 3,694 & 0.56 & 2,056 \\
\hline China, People's Republic of & 3,829 & 0.34 & 1,534 \\
\hline European Union & 558 & 1.42 & 795 \\
\hline Greece & 428 & 1.39 & 596 \\
\hline Spain & 130 & 1.53 & 199 \\
\hline Turkey & 791 & 0.36 & 287 \\
\hline Brazil & 700 & 0.06 & 44 \\
\hline Mexico & 135 & 0.21 & 28 \\
\hline Egypt & 235 & 0.09 & 20 \\
\hline \multicolumn{4}{|l|}{ Memorandum item: } \\
\hline World cotton price & & 1.25 & \\
\hline
\end{tabular}

Source: International Cotton Advisory Committee.

1/ Average.

Figure 1. Nominal Price, Real Price and World Stocks of Cotton, Jaruary 1985 - December 2002 1/

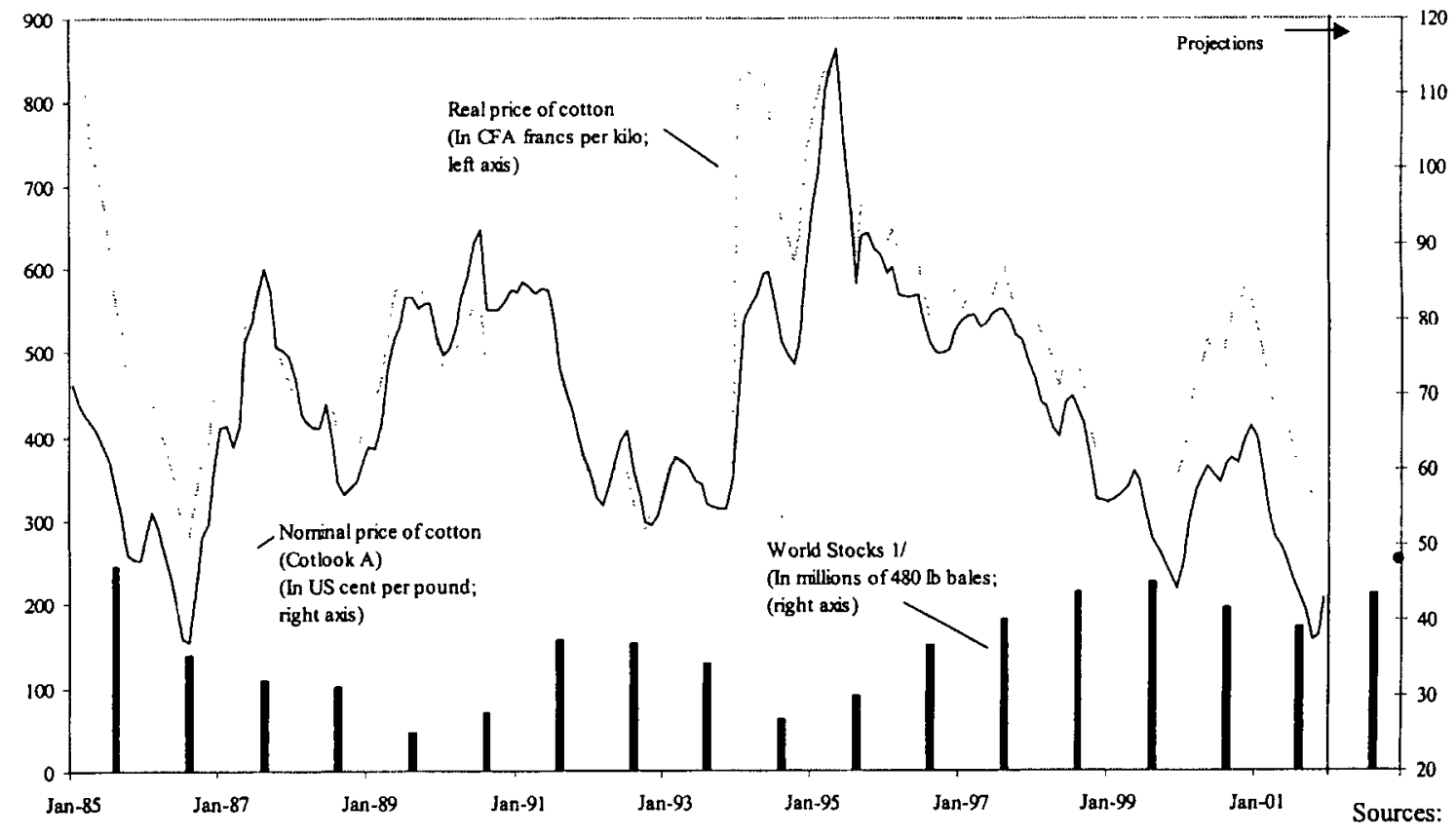

USDA; and IMF staff.

1/ Stocks reported in August, the last month of the cotton marketing year. Real cotton price relative to average WAEMU CPI, based in 1990. 
through a reference price system for cotton. Currently, the procurement and marketing of cotton are monopolized by the government and the procurement and sales prices are determined largely to subsidize the farmers. This has resulted in domestic prices that are about 20 percent higher than world prices. After China's entry to the WTO, the state-trading monopoly will be phased out, and domestic prices should move closer to international prices. In the United States, the program of agricultural support is notable because it has been based on the assumption that agricultural prices would remain stable or increase slightly; the program was designed in 1996 to enhance the role played by market forces in production decisions. As production expanded and prices started to fall, the level of subsidies increased significantly. Instead of facilitating the adjustment of production to the excess supply and declining prices, the U.S. price supports have led to increasing production in the United States by making cotton more profitable than competing crops like soybeans, corn, or sorghum. ${ }^{4}$ For instance, U.S. cotton farmers are expected to receive more support in the current crop year than in 1999 , when cotton prices were also at very low levels. ${ }^{5}$

The U.S. agricultural support programs are up for renewal before the end of the current fiscal year, in September 2002. ${ }^{6}$ The farm bill proposals to renew these programs, now being considered in Congress, would essentially (a) lock in place levels of spending that have been inflated in recent years by "emergency" funding measures, (b) introduce a new countercyclical element tied to product prices, and (c) expand the programs' coverage to other agricultural products. The proposed new farm legislation would contribute to continued overproduction and it would lower world prices of the agricultural products covered by the programs--- in particular cotton---which would perpetuate the problems faced by WCA exporters.

\section{The Cotton Sector in West and Central Africa}

This section describes the current situation in the cotton sectors of the region, and the next section outlines the reform agenda. While cotton production has expanded rapidly, the share of the international price paid to producers has been relatively low, reflecting inefficiencies

${ }^{4}$ U.S. farmers receive benefits under a number of government programs: production flexibility contract and commodity loan programs, subsidized crop and revenue insurance, and market loss assistance. U.S. policies have resulted in a decoupling of the U.S. price for cotton that farmers receive from the world price. Despite historically low world cotton prices, prices received by U.S. farmers have actually increased since early 2001, if the value of the loan programs (as a per-unit subsidy) is included.

${ }^{5}$ See Leslie Meyer and Stephen MacDonald, "Cotton: Background and Issues for Farm Legislation," U.S. Department of Agriculture, Economic Research Service, July 2001.

${ }^{6}$ See United States: Selected Issues - Country Report No. 01/145, August 24, 2001.

Washington DC: International Monetary Fund) 
in the ginning, marketing, and input distribution subsectors. A transition toward more competition and transparency and hence greater efficiency in processing and marketing of cotton should allow WCA countries to raise production further and expand their export market shares.

\section{Production and Ginning Performance}

Cotton production in West and Central African countries has increased fourfold since the early 1980s (Figure 2). Cotton has proved to be an economically viable crop that has had a significant and positive impact on exports, economic growth, and rural development. Cotton ginning, input supply, transport, and marketing constitute significant economic activities in most of these countries. Cotton-related activities account for a large share of rural employment and exports, and generate a significant share of government revenue.

Figure 2.

Cotton Production in CFA Franc Zone and Rest of Sub-Saharan Africa, $1980-2001$

(In thousands of metric tons)

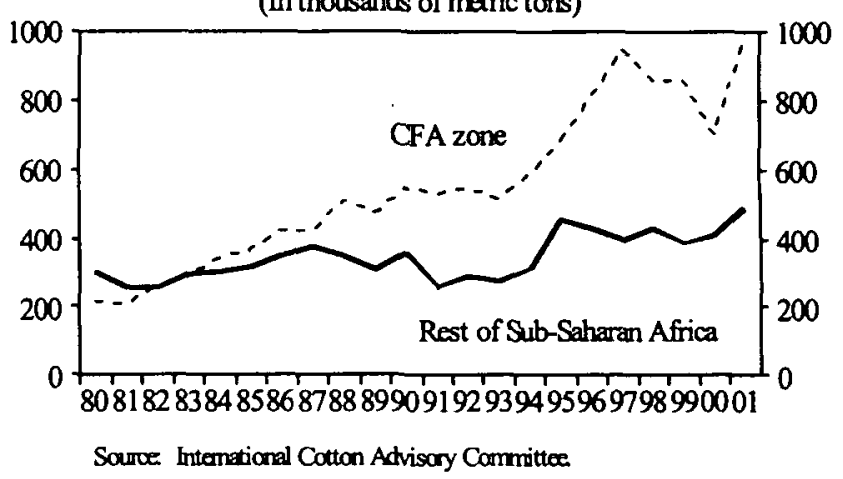

With the exception of Benin, cotton production stagnated or declined in the WCA countries in the six years preceding the devaluation of the CFA franc in 1994, but accelerated after the devaluation (Table 3). Production increased by 16 percent a year on average from 1993-94 to 1997-98, then declined for three years, before reaching a new peak in 2001-02. Over the past four years, production increased substantially in Mali, Côte d'Ivoire, Burkina Faso, and Cameroon; it declined slightly in Benin and markedly in Chad and Togo.

The development of the sector has resulted in consistently good-quality cotton, high average crop yields (by international standards), and high ginning ratios. In 1995-96, farm yields were in the range 1000-1200 kg/ha, except in Burkina Faso and Chad, where they were below $1000 \mathrm{~kg} / \mathrm{ha}$. Ginning ratios, at about $40-43$ percent, are also high in the WCA countries by international standards. By contrast, ginning ratios are closer to 34-36 percent for similar cotton in India, and in Zimbabwe they are around 39 percent. Several factors have contributed to successful cotton production in the region: application of appropriate soil nutrient replenishment, pest management, and seed varieties well suited to local conditions; the provision, by the government and/or the cotton companies, of support services and infrastructure; guaranteed producer prices and output markets; high input-credit recovery rates; and well organized village-level associations.

\section{Institutional Environment}

Despite the sector's historically strong performance, its institutional environment has led to numerous inefficiencies, which provide considerable scope for improvement. For instance, in all but two countries (Benin and Côte d'Ivoire), the cotton sector is under the control of a 
single company that controls the provision of inputs and other services to farmers, and operates as the sole buyer of the entire cotton crop. With the exception of Burkina Faso, national governments are majority shareholders of these companies. The lack of transparency under these managed monopoly systems creates a multitude of opportunities for rent seeking and the mismanagement of resources, generally at the cost of farmers, the national budget, and the economy as a whole. ${ }^{7}$ In particular, it severely limits incentives to minimize costs, and it stifles entrepreneurial decision-making at all levels of the supply chain.

Essentially, the viability of national sectors under the current system is based on their ability to (a) tax producers and accumulate profits in times of high export prices, and (b) rely on budgetary support from national governments in times of low international prices. This strategy has not worked well in many countries owing to poor management of the stabilization fund by the cotton monopsonists. This strategy needs to be changed in an era of

\footnotetext{
${ }^{7}$ Various sector diagnostic studies and technical audits of cotton companies that have been carried out in many countries over the years have repeatedly documented a considerable level of rent seeking and relatively high operating costs in the ginning sector. The latest examples are the technical audit of CMDT in Mali in 2000 and the survey of ginning costs in Benin in 2001 .
} 
Table 3. West and Central African Countries: Production and Net Exports of Cotton, 1980/81-2001/02 (In thousands of metric tons)

\begin{tabular}{|c|c|c|c|c|c|c|c|c|c|}
\hline & $1980 / 81$ & $1985 / 86$ & $1990 / 91$ & 1993/94 & $1997 / 98$ & $1998 / 99$ & $1999 / 00$ & $2000 / 01$ & $\begin{array}{r}2001 / 02 \\
\text { Proi. }\end{array}$ \\
\hline & \multicolumn{9}{|c|}{ Production } \\
\hline Benin & 4 & 32 & 59 & 116 & 152 & 142 & 150 & 131 & 136 \\
\hline Burkina Faso & 23 & 46 & 77 & 51 & 138 & 120 & 110 & 114 & 164 \\
\hline Cameroon & 32 & 46 & 44 & $\$ 1$ & 76 & 78 & 75 & 94 & 95 \\
\hline Central African Republic & 8 & 13 & 12 & 7 & 20 & 16 & 11 & 9 & 11 \\
\hline Chad & 31 & 39 & 60 & 37 & 109 & 65 & 76 & 65 & 76 \\
\hline Côte d'Ivoire & 56 & 82 & 116 & 114 & 147 & 157 & 164 & 125 & 164 \\
\hline Mali & 43 & 68 & 115 & 101 & 216 & 218 & 196 & 105 & 240 \\
\hline Senegal & 7 & 11 & 12 & 15 & 17 & 5 & 9 & 9 & 14 \\
\hline \multirow[t]{2}{*}{ Togo } & 9 & 27 & 41 & 33 & 65 & 76 & 57 & 49 & 60 \\
\hline & \multicolumn{9}{|c|}{ Net Exports } \\
\hline Benin & 6 & 27 & 50 & 105 & 141 & 131 & 142 & 136 & 125 \\
\hline Burkina Faso & 21 & 44 & 69 & 44 & 120 & 114 & 113 & 113 & 147 \\
\hline Cameroon & 27 & 38 & 34 & 37 & 63 & 65 & 65 & 81 & 82 \\
\hline Central African Republic & 5 & 11 & 9 & 3 & 17 & 15 & 10 & 8 & 9 \\
\hline Chad & 33 & 44 & 57 & 33 & 101 & 63 & 72 & 65 & 65 \\
\hline Côte d'Ivoire & 43 & 84 & 81 & 80 & 98 & 120 & 160 & 109 & 131 \\
\hline Mali & 38 & 60 & 98 & 87 & 174 & 202 & 196 & 125 & 196 \\
\hline Senegal & 4 & 7 & 7 & 11 & 11 & 2 & 3 & 4 & 8 \\
\hline Togo & 7 & 22 & 36 & 35 & 57 & 65 & 55 & 47 & 55 \\
\hline
\end{tabular}

Source: International Cotton Advisory Committee.

increasing globalization and regional integration. The fact that producer organizations are getting stronger reduces the room for taxation in the future. Similarly, increased pressure on budgetary resources will reduce the ability of governments to rescue national parastatals during future crises.

The current pricing system provides some stability to farmers, but at a high cost in terms of income foregone and lower long-term growth potential. Table 4 illustrates the impact of the current system on pricing in individual countries in West and Central Africa. ${ }^{8}$ Before the devaluation of the CFA franc in 1994, producer prices in the WCA countries were about half of the international levels. In the period immediately following the devaluation of the CFA franc (1994-95 to 1996-97), producer prices in the CFA franc countries declined significantly as a ratio to international prices; this was due to deliberate domestic policies to consolidate fiscal positions and lower inflationary pressures. During the period 1997-98 to 2000-01, producers' shares increased to slightly above their pre-devaluation levels on average. Nonetheless, this ratio was higher in countries such as Benin and Côte d'Ivoire, which were relatively more advanced in the implementation of structural reforms in the sector.

\footnotetext{
${ }^{8} \mathrm{Part}$ of the difference in this ratio across countries is explained by the higher transport costs from ginneries to seaports in landlocked economies.
} 
Table 4. Cotton Fiber: Ratio of Domestic Producer Price to International Price 1/

\begin{tabular}{lcrcccccc}
\hline & Benin & $\begin{array}{r}\text { Burkina } \\
\text { Faso }\end{array}$ & Cameroon & Chad & $\begin{array}{c}\text { Côte } \\
\text { d'Ivoire }\end{array}$ & Mali & Togo $\begin{array}{r}\text { Average } \\
\text { countries }\end{array}$ \\
\hline $1988 / 89-1993 / 94$ & 52 & 54 & 48 & 48 & 51 & 46 & 49 & 50 \\
$1994 / 95-1996 / 97$ & 41 & 39 & 38 & 35 & 41 & 36 & 40 & 39 \\
$1997 / 98-2000 / 01$ & 59 & 51 & 50 & 49 & 55 & 48 & 57 & 53 \\
\hline
\end{tabular}

Sources: Data on producer prices are from Pursell, "Cotton Policies in Francophone Africa", presented at a World Bank workshop, May 2001; interternational price series are from IMF, World Economic Outlook database; and recent producer prices are from IMF desk economists.

The relatively large gap between the domestic producer prices and lint equivalent export prices of seed cotton is explained primarily by (a) the rising operating costs of the cotton companies (Figure 3); (b) the implicit subsidies to other areas of the sector offered by the cotton parastatals (to private ginneries, for example, as well as to the domestic oil and meal processing companies); and (c) the provision of a variety of public services (for example, infrastructure maintenance, provision of schooling, and health services) by the cotton companies in the cotton growing regions.

\section{The International Competitiveness and Growth Potential of WCA's Cotton Sector}

The competitiveness of the region's cotton sector is evidenced by the low level of costs when compared to other countries, and by the strong growth in production over the last two decades. Comparisons of the costs of production by the various cotton producers of the world are difficult to make because of incomplete data. The most comprehensive source is from the International Cotton Advisory Committee (ICAC), which performed a survey of the cost of producing raw cotton in 2001-02 in 28 countries, including the largest producers (China, the United States, India, Pakistan, and Uzbekistan), four countries in WCA, and six others in Sub-Saharan Africa. It should be stressed that these data are also imperfect, however, the survey revealed that WCA countries were among the world's lowest cost producers. The current decline in world prices has illustrated the level of competitiveness of WCA's cotton sector. Although subsidies in the order of US $\$ 50$ to $\$ 60$ million were required for the zone as whole to cushion the effect of falling world prices, the national cotton sectors would have been profitable if the international price had exceeded 50 cents per pound. Few other countries can produce cotton profitably at this price level. 
WCA countries can produce cotton cheaply, and cotton is generally far more profitable than alternative crops in many parts of the region. While farmers can shift relatively easily from cotton to soybeans in the United States, Australia, or Brazil depending on relative prices, growers in many WCA countries have much less scope for substitution. In Burkina Faso, the main choice is between the cotton/maize mix, or niebe alone. As shown in Table 2, cotton production in WCA's most important competitor countries takes place under heavy subsidization. Farmers in the two main producing countries -.- countries that account for almost half of world production---enjoyed support as high as 20 percent of world prices in the case of China, and 50 percent in the case of the United States, while EU subsidies exceeded 100 percent. Producers in the WCA region are currently the main losers with respect to global policies, being penalized both domestically through implicit taxation, and in international markets due to subsidies in competing countries. There is no question, therefore, that producers in WCA countries would significantly benefit from a less distorted international environment for cotton production.

According to estimates made using the ICAC world textile demand model, the removal of U.S. subsidies would produce a fall in U.S. production that would lead to a rise in the international price in the short run by as much as 12 cents per pound. ${ }^{9}$ Such an increase in the world price of cotton would increase revenues from cotton by about $\$ 250$ million in WCA countries, which compares to the total flow of overseas development assistance (ODA) to the region of $\$ 1.8$ billion in 1999 , and $\$ 50$ to $\$ 60$ million of subsidies provided to WCA farmers in the current crop year to cushion them from the fall in prices. Elimination of government subsidies in the United States and China, by far the world's largest producers and the world's largest exporter in the case of the United States, would stimulate a reallocation of production toward lower cost producers, including those in West and Central Africa. Though the long-term price increase may be smaller than indicated by the above estimates, due to induced adjustments in production and consumption, the impact on longterm growth and poverty reduction in Africa would be significant. Reduction in the proportion of cotton production that is insulated from market forces as a result of government price support could also be expected to lower the volatility of the (free) world cotton price. Greater market stability would improve the environment for trade and encourage production in more competitive exporting countries such as those in the WCA region.

\section{The Reform Agenda: The RoAd TOWARd Competitive Cotton SECTORS}

The long-term strategic objective in the cotton sector is to increase and sustain its contribution to poverty reduction through employment creation and income generation in the rural areas, and to contribute to export earnings and government revenues. Growth linkage research in the West Africa region has shown considerable multiplier effects on employment and income in the rest of the rural economy due to the expansions in income from cash crops. The implications of sustained growth in the cotton sector or lack thereof for poverty

\footnotetext{
${ }^{9}$ Becerra, 2000, op. cit. Reduction of EU subsidies could be expected to have a similar, but much smaller, effect given the significantly lower level of production that is involved.
} 
reduction, as well as the need for reforms to bring about such growth, should therefore be looked at from that much broader angle rather than from the immediate impact within the sector, or from the short-term effects on public finances.

Since individual countries in WCA are at different stages in their progress toward establishing competitive sectors, the reform agenda needs to take into account the situation in each country. The following sections present roadmaps for reforming individual cotton subsectors that depend on the institutional environment in each country. The sections summarize the main features characterizing the various subsectors in the current situation; describe the key features that would indicate successful reforms of these sectors; specify short-term target changes that need to be achieved in order to move toward competitive national cotton sectors; and identify specific actions that need to be undertaken by governments, private sector stakeholders, and development partners.

Since 1998, intensive consultations have taken place between the Bank and the IMF, the French Cooperation, national governments, producer organizations, and ginning companies to reach a consensus. The reform agenda that is outlined below reflects the progress that has been achieved toward that goal. This growing consensus was confirmed in July 1999 in Ouagadougou at the regional symposium on the future of the cotton sector in West and Central Africa. An important conclusion that came out of that symposium is the need to introduce competition at all levels of the sector in order to raise efficiency and sustain growth.

Experience suggests that successful reform of the cotton sector to achieve a competitive system is bound to take several years to complete. The reform plan has to be properly sequenced and managed so as to limit disruptions that could be detrimental to production. In most cases, however, the principal steps of the reform process would involve (a) spinning off to the private sector the non-core activities of the cotton parastatals (including extension services, transport activities, purchase and distribution of inputs and equipments, and marketing of seed cotton and cottonseeds); (b) reinforcing the technical and commercial capacities of farmer associations so they can directly contract for bank credit through a private-sector-based recovery system that links repayment of credit to the marketing of the seed cotton; and (c) introducing competition by opening up the sector to private ginneries, which in most cases would require privatizing ginneries that are owned by the parastatals. In addition, the marketing of fiber needs to be performed through transparent and competitive bidding processes. Over the short- to medium-term, there is considerable scope to lower the operating costs of the inefficient cotton monopsonies.

It bears emphasizing that the reform process would require that development partners provide the necessary technical assistance in support of programs to effect a successful transition to open and competitive systems. This approach is working well in Benin, where the IMF, World Bank, and bilateral donors have worked closely with the government and the private sector to facilitate the reform process. Similar support is also being provided to the cotton sector in Mali and will need to be extended to other countries in order to raise the chances of success in reforming the sector. 


\section{The Provision of Input Credit}

Successful reform of this subsector would ensure effective credit recovery while allowing for the emergence of competitive primary marketing. Currently, credit recovery is achieved in two ways. In all but one country, the ginning companies, public or private, serve as intermediaries for the input credit, which they also recover on behalf of commercial banks or traders. In the remaining case (Benin), the recovery of credit is carried out through a privatesector-based Agribusiness Trade Association (ATA) type mechanism and does not involve ginning companies. While the latter system maintains the critical, direct link between seedcotton payment and credit recovery, it eliminates the intermediation by ginning companies, which, in the case of state companies, has attracted rent seekers with little interest in undertaking long-term investments in input distribution activities. In fact, the system in Benin replaces the traditional intermediation / guarantee by the state company through a series of contracts between the private sector operators that are involved. Therefore, the next step in the transition under this system should be the development of an effective contract enforcement system to protect the integrity of the new mechanism. The transition in the remaining countries would involve two steps that could be carried out simultaneously or sequentially: (a) reduction of credit intermediation costs; and (b) the introduction of a private-sector-based recovery system, perhaps first of an ATA-type model like in Benin, which would operate well under a competitive contract farming system.

The strategic objective in this subsector is to sustain the broad access by farmers to input credit at reasonable cost by encouraging the development of recovery mechanisms that are more transparent and compatible with competitive primary marketing systems. In the context of limited farmer assets and underdeveloped financial markets, these mechanisms would have to maintain a direct link between the payment of seed cotton and the recovery of input credit. The mechanisms would operate best when owned and managed by the private sector, but they will require assistance both from national governments and development partners.

\section{Marketing of Seed cotton}

Primary marketing should be conditioned by the requirements for an effective input credit recovery mechanism. The indicator for successful reform should, therefore, be the emergence of a marketing system that allows free entry without jeopardizing the recovery of input credit. Judging from the experience in WCA, such a system would have to link seed-cotton payment directly to input credit recovery. The least complicated and least risky transformation that would satisfy this condition would lead to a system of competitive contract farming, at least during the initial years. Under contract farming, local farmer organizations would negotiate prices and sales contracts, on an annual or multi-annual basis, with one or several ginning companies. These contractual arrangements would provide member farmers with the necessary legal and institutional tools to tackle many of the production and marketing problems that they face, ranging from technology generation and 
dissemination, to credit access, input procurement, product quality, and price stabilization. For instance, sales contracts could be used to provide collateral for input credit, and ginning companies could collaborate with local producer organizations in purchasing insurance and other instruments to stabilize prices and incomes. To ensure the success of contract farming, the technical and commercial capacities of local farmer organizations would have to be strengthened significantly to allow them to adequately negotiate and enforce contracts with ginning companies and other private sector operators, including commercial banks and input distributors.

Currently, three types of primary marketing systems exist in the region. The first, which prevails in all but two countries, Benin and Côte d'Ivoire, corresponds to the traditional onecompany-monopoly model. The second system is the one in Côte d'Ivoire, where the traditional national-level monopoly has been replaced by three geographic monopolies. A third system was adopted in Benin, where the monopoly of the national cotton company was lifted and prices and marketing decisions are now negotiated among private sector operators at the national level. In the three cases where several ginning companies exist (Benin, Côte d'Ivoire, and Togo), the price of seed cotton is de-linked from the allocation of quantities among these companies. In the case of Benin and Togo, the allocation of seed cotton is done on the basis of the share of installed ginning capacities. In Côte d'Ivoire, the quantity of seeci cotton that a company receives is in principle determined by the level of production within its assigned geographic area. In all these cases, the prevailing system does not allow for competition for seed cotton among ginners. Moreover, it penalizes efficient ginning companies and rewards less efficient ones.

The move toward a system of competitive contract farming would allow for decentralized pricing, eliminate the administrative allocation of seed cotton, and encourage competition among ginning companies. This would, however, require organizational, technical, and commercial capacities on the part of producer organizations that are currently underdeveloped. Consequently, the next step in the transition, which should be carried out in parallel to the strengthening of the capacities of producer organizations, should be to set up private-sector-based mechanisms to negotiate pricing and marketing decisions. This move should be combined with the removal of geographic monopolies, in the case of Côte d'Ivoire, and the lifting of the monopoly of national companies over seed-cotton marketing in the remaining countries; in addition, sector-based input recovery mechanisms should be put in place. In Benin, the next move should be to decentralize the negotiation process. Once the capacities of local producer organizations have been sufficiently strengthened, sectors could graduate to systems where ginning companies negotiate pricing and marketing decisions directly with local producer organizations.

An important step that needs to be considered part of the reform of domestic marketing systems, is the removal of barriers to cross-border trade in seed-cotton. All cotton growing countries considered in this paper are members of regional integration bodies that have enacted policies to create common regional markets in West and Central Africa. Moreover, cotton is a major tradable commodity, and allowing cross-border trade would raise 
competition for seed cotton, improve producer incomes, and create incentives for investment in the sector.

\section{Cotton Ginning}

Currently the ginning industry is characterized by two modes of organization: one that is based on a single-company-monopoly system and another that is based on managed coexistence between public and private companies. In countries where a single-company monopoly exists, the following three steps should be taken immediately: (a) open up the sector and bring in new entrants, (b) ensure that national companies reduce unit costs by rationalizing ginning operations and spinning off non-core businesses such as transport and oil mills, and (c) maximize revenues by selling cotton seeds at competitive prices and adopting efficient fiber export arrangements. In countries where private ginning companies are already operating, the next step in the transition is to move toward more competition between state and private companies commensurately with the reforms in the input and primary marketing sectors. At this stage, countries should move to open up regional markets for seed cotton and allow ginners to compete for seed cotton at the regional level, thereby encouraging greater efficiency among ginning companies.

The ginning subsector has been one of the main sources of inefficiencies in the supply chain, hence the strategy to promote competition and thereby greater efficiency in this subsector. Beyond the regulatory frameworks for contract enforcement that have been referred to in the preceding sections, national governments would have to facilitate the entry of new operators and competition by privatizing the national companies. The latter should preferably be carried out in separate entities in order to avoid the emergence of private monopolies. The support to be provided by donors would include assistance for the planning and implementation of the privatization processes and the strengthening of national capacities for contract enforcement.

\section{Import and Distribution of Fertilizers and Pesticides}

Successful reforms in the fertilizer and pesticide subsectors should lead to competitive private-sector-based importation and distribution systems. Three different institutional constellations are discernable currently, corresponding to the following cases: (a) where the national company is alone in charge of the procurement and distribution system; (b) where the national company imports through private importers but remains in charge of the distribution process; and (c) where an ATA organizes the procurement process on behalf of farmers, but importation and distribution are handled by private operators. In the transition process, one could envisage countries moving progressively from the first to the third constellation. In that process, countries in which the national company is directly in charge of importation and distribution, the next step would be to move to a system where the company imports through private traders. The subsequent step would be to set up an ATA-type mechanism to take over the organization of the procurement process from the national 
company. These two steps could be taken simultaneously, in cases where farmer organizations have sufficient capacities to set up and manage such a mechanism. In countries where such a system already exists or where the national company procures through private traders, the immediate next step should be to establish transparent competitive bidding procedures. The systems at this stage should attract only professional importers and distributors who are able to mobilize the necessary financial resources and are willing to make long-term investments in import and distribution activities. The final move from the ATA-type system to a fully decentralized procurement system would depend on the availability of an effective input credit recovery mechanism and the degree of decentralization of primary cotton marketing. The move becomes less urgent, however, if the ATA-based system is coupled with transparent and competitive bidding procedures.

The strategic objective should be to sustain the broad access to quality products that has been achieved under the administered monopoly but in the context of competitive import and distribution systems. In addition to removing barriers to entry, national governments would have to enact and enforce adequate regulatory systems to protect contract rights, maintain quality standards, and safeguard human health and environmental safety. The private sector would complement these efforts by establishing ATA-type institutions to coordinate the provision of sectorwide technical support services, which would raise the demandresponsiveness and facilitate the contribution of beneficiaries to the financing of those services. The role of the Bank and other donors would be to assist in building national capacities for the development and implementation of regulatory systems and providing support to ATA institutions.

\section{Seed Production and Multiplication}

Two organizational structures are currently observable for the seed subsector among WCA countries. The first involves a system where the cotton company finances the research program, controls the seed distribution system, and works with contract farmers for the multiplication of improved seed. The second, about to be instituted in Benin, consists in an ATA-based system of co-financing research and extension services; subcontracting seed multiplication for distribution through local farmer organizations. The objective in both cases should be the establishment of well functioning private-sector-based multiplication and distribution systems. In the first case, the immediate next step in the transition should be to move toward an ATA-based system; in the second case, the next move should be toward expanding the role of the private sector both in seed multiplication and distribution. The pace of transition in both cases would be limited by the level of development of the private sector.

Continued access to high quality seeds through cost efficient multiplication and distribution systems should be the strategic objective in the seed sector. The accompanying measures that are called for here are basically the same as in the case of the fertilizer and pesticide sectors. However, in addition to enacting and enforcing adequate regulatory systems, governments would have to support and improve the performance of the national research systems. The private sector would also have to put in place institutional mechanisms that would enable it 
to participate more effectively in setting research priorities and augmenting the limited public resources to finance strategic research for the sector. Assistance by donors would help develop national regulatory systems and support research.

\section{Pricing Policies}

For the current crop year (2001-02), farm-gate prices have already been set, and additional financing is being sought to cushion farmers for some of the drop in world prices. For the next crop year, the following general principles should guide the countries of WCA: pricing mechanisms adopted for 2002-03 should not call into question the objectives of enhanced competition and privatization, nor should they roll back the reforms that have occurred. Thus, in Benin, where there is a publicly owned ginning company and six private companies, and where the prices are agreed upon among ginners, producers, and other market participants, a return to government-set cotton prices should be avoided.

Moreover, in countries where a government-owned monopoly remains, prices paid to growers should reflect fluctuations in the world price just as they would in a competitive environment with private ginning companies, which is the medium-term goal. Countries should not attempt to resist the influence of world prices, in particular by taking on a commitment to keep domestic prices artificially high in the face of low world prices. Doing so could imply unreasonably large budgetary costs. Thus, governments should strictly limit the extent of the subsidies they provide to cotton growers and ginning companies. Until reforms have produced a framework for competition among ginning companies, price setting (and hence the division of the proceeds from selling lint cotton) should in any case emerge from a transparent and equitable mechanism, agreed upon among the market participants (producer groups, the state, ginning companies, and financing institutions providing input and crop credits). In the past, it has been the case that ginning companies have justified low prices paid to producers on the basis of inflated costs. Ginning companies should be audited and compared to best-practice firms elsewhere.

Pricing mechanisms differ with respect to who bears the risk of price fluctuations over the course of the harvest. Two opposite cases can be envisioned. In the first case, the price to be paid for cotton is set at planting time; as a result, the risk of price fluctuations between planting and harvest is borne by the ginning company or the government. In the other case, no price is quoted to producers until the cotton is delivered to the ginning company and sold by the latter. In this case, all the risk is borne by the producers, those least able to do so. In most countries, some variant of the first case has been adopted. However, a problem with this system is that it often requires the government to step in with subsidies, which essentially shoulders the downside risk.

Since effective competition among ginning companies does not yet exist, an intermediate pricing mechanism that shares some of the risk between producers, ginning companies, and the government may be desirable for the 2002-03 crop season. For instance, in most countries with a single monopoly company and no private ginneries, such a mechanism could 
guarantee a minimum price to producers at the start of the season, with a top-up later if world prices remained at the initial level or increased. Ginning companies could hedge some of this risk by selling forward, but full hedging is impossible, since the size of the crop is not known and the cost of hedging could be prohibitive in some circumstances. In this system, both producers and growers share some of the risk (and all players could increase their receipts when world prices improve, in proportions that are equitable and defined in advance). Such a practice would be similar to the ristourne (rebate) which is familiar to growers in the region, but would differ from it on one major point: The second payment would not be based on the ginning company's surplus, but instead on the excess of the world price over the value that had been assumed in setting the guaranteed price. The excess could be shared between growers and ginners according to the percentage agreed upon when the guaranteed price was set; the state would also benefit through higher taxes on ginning company profits. The ginning companies would have an incentive to reduce their costs since doing so would boost profits. Such a scheme would not eliminate the risk of subsidy, but it would considerably reduce it if the guaranteed price were sufficiently conservative.

Past attempts at reducing the impact of price fluctuations on growers' incomes through stabilization funds have not been very successful. One of the reasons for this failure has been the lack of a clear understanding between growers, ginneries, and the state as to the ownership and control of the funds' resources. In Mali, for instance, growers feel that the stabilization fund resources have been largely used at the discretion of the cotton parastatal (CMDT) to cover deficits of its own making. In Burkina, on the other hand, where the fund is clearly owned and controlled by growers, the resources are better managed and protected from the cotton company. As a consequence, the resources are available for use to stabilize prices, and government subsidies are not expected to be required in 2001-02.

Reforms of the cotton sector and the price setting mechanisms should lead export proceeds to be distributed more fairly through transparent negotiations between the parties, and each party should have the responsibility to manage its own price risk. Ginneries could cover their price risks just like any other private enterprise would. Growers are not well equipped to cover price risks on their own, since their savings are generally invested in the form of animal husbandry, which cannot be easily disposed of when cotton prices fall. But village associations at the local or national level could enter into contractual obligations with private insurance companies that could provide them with income protection for an acceptable premium. Such arrangements would limit the need for government intervention.

\section{E. Conclusions}

The cotton sector in WCA is currently undergoing difficult times due to the historically low world price, partly reflecting generous subsidies to cotton growers in the United States, China, and the European Union, and the slow transition to competition among private ginning and marketing companies. Cotton is a key component of any program of rural poverty reduction in the WCA region, given its importance for the exports of these countries. Prospects for poverty reduction would be considerably improved by removal of subsidies by industrial and other developing countries, which are increasing the supply artificially and 
putting downward pressure on world prices. The WCA countries would benefit greatly from removal of price supports and subsidies to cotton growers in the other parts of the world.

Prospects for poverty reduction in the WCA countries would be improved with the reform of the cotton sectors in order to enhance competition and allow a larger share of the world price to be passed through to farmers. An objective of the reforms should continue to be the development of a sector in which the government has limited involvement in setting prices or providing subsidies. Privately owned ginning companies should compete with each other in determining prices, which would be agreed upon in an open and transparent manner. Such a system would require institutions to ensure credit recovery, so that purchases of inputs could be financed. Thus, it will be important to develop growers' associations and legal mechanisms for collecting debts. Though such institutions and competition among private ginning companies will not develop in time for the next crop year, it is important to continue to make progress toward this objective. In the meantime, the pricing mechanisms that are adopted should not call into question the objectives of enhanced competition and privatization, and they should not roll back the reforms that have already occurred. 


\section{EVOLUTION \\ DES FILIÈRES COTONNIERES \\ EN AFRIQUE DE L'OUEST ET DU CENTRE}

par

Ousmane Badiane

Dhaneshwar Ghura

Louis M. Goreux

Paul R. Masson*

July 2002

*) Les auteurs sont, respectivement, Coordonnateur Principal, Politiques Alimentaires et Agricoles, Région Afrique, Banque Mondiale; Chef de Division Adjoint, Département Afrique, Fonds Monétaire International; Consultant, Banque Mondiale; et Conseiller Principal, Département Afrique, Fonds Monétaire International. 



\section{RÉSUMÉ ANALYTIQUE}

La production cotonnière a amélioré le bien-être des populations des zones rurales et contribué à la croissance économique des pays d'Afrique de l'Ouest et du Centre (AOC), membres de la zone franc. La production a quadruplé au cours des deux dernières années, hissant la région au rang de deuxième exportateur mondial de coton, avec une part d'exportations mondiales d'environ $15 \%$. Le coton est la principale culture de rente et la principale source de recettes d'exportation et de recettes publiques de plusieurs pays de la région. La culture du coton emploie plus de deux millions de ménages en zone rurale et, de ce fait, elle constitue un facteur essentiel dans la lutte contre la pauvreté.

En dépit du succès enregistré dans la promotion de la culture du coton, le système de monopsones nationaux de coton intégrés en place actuellement présente des faiblesses. Il repose, notamment, sur i) la capacité des monopsones à imposer les producteurs et à accumuler des bénéfices lorsque les prix à l'exportation sont élevés et ii) la disponibilité des appuis budgétaires de l'État en période de baisse des cours mondiaux. Ainsi, le récent repli des cours mondiaux aurait pu se solder par une chute brutale des recettes des cultivateurs n'eut été l'assistance octroyée aux gouvernements par la communauté de donateurs.

Depuis plusieurs années, la Banque et le FMI préconisent des réformes tendant à :

- Autoriser l'entrée libre dans la filière coton et la concurrence à tous les niveaux, y compris le commerce transfrontalier de coton-graine;

- Mettre en place des mécanismes privés qui permettent de maintenir le lien entre le recouvrement efficace des crédits octroyés au titre de l'achat d'intrants et la commercialisation du coton-graine;

- Adopter des mécanismes de prix qui permettent aux prix à la production de répercuter les variations des cours mondiaux;

- Mettre en place des mécanismes dans le secteur privé en vue de réduire les risques de prix;

- Renforcer les capacités techniques et commerciales des associations de producteurs afin de faciliter leur participation à un régime volontaire d'agriculture contractuelle, à la distribution d'intrants et à la prestation de services agricoles;

- Créer des organisations professionnelles qui permettent au secteur privé de participer efficacement à la coordination et au financement de services d'appui techniques dans toute la filière;

- Améliorer la prestation de services, notamment la recherche, la vulgarisation et les contrôles phytosanitaires, où les pouvoirs publics jouent un rôle essentiel dans le financement des biens publics.

L'expérience montre qu'il faudra plusieurs années pour mener à bien la mise en œuvre du programme de réformes décrit ci-dessus. Comme il est expliqué dans le document, les pays 
d'Afrique de l'Ouest et du Centre se trouvent à des stades différents de progrès vers la mise en place de filières compétitives. S'agissant de la prochaine campagne, les mécanismes de détermination de prix adoptés ne doivent pas remettre en question les objectifs de renforcement de la concurrence et de privatisation et encore moins les réformes déjà mises en œuvre. Les chances de faire reculer sensiblement la pauvreté en Afrique de l'Ouest et du Centre seraient considérablement améliorées si les réformes mentionnées ci-dessus étaient mises en cuvre.

Parallèlement, les subventions dont bénéficient les producteurs de coton dans les principaux pays producteurs gonflent artificiellement l'offre sur les marchés internationaux et dépriment les prix à l'exportation pour les pays d'Afrique de l'Ouest et du Centre. Les pressions à la baisse sur les prix à l'exportation sont exacerbées par des subventions généreuses - et en accroissement rapide dans le cas des États-Unis - pour la production du coton aux ÉtatsUnis, en Chine et dans l'Union européenne. Les pays d'Afrique de l'Ouest et du Centre profiteraient de l'élimination de ces subventions et tireraient mieux parti de leur avantage comparatif dans la production de coton en vue de promouvoir la croissance et de faire reculer la pauvreté. 


\section{A. INTRODUCTION}

La chute récente du cours mondial du coton a entraîné une chute des recettes d'exportation et des recettes budgétaires de quelques-uns des pays les plus pauvres d'Afrique, à un moment où nombre de ceux-ci sont en train de restructurer leurs filières cotonnières afin de les rendre plus compétitifs et moins tributaires de l'État. La filière coton des pays d'Afrique de l'Ouest et du Centre, membres de la zone franc ${ }^{\prime}$ jusqu'à une date récente, se réduisait d'une seule société parapublique qui fournissait les intrants et d'autres services aux agriculteurs et qui achetait la totalité de leur récolte cotonnière. Bien que ce système ait contribué à augmenter sensiblement la production de coton, il a aussi permis de verser aux agriculteurs des prix inférieurs à ceux qui sont pratiqués dans les pays producteurs de coton qui suivent un régime plus compétitif. S'agissant des pays d'Afrique de l'Ouest et du Centre membres de la zone franc, le coton est leur principale source de recettes d'exportation; il est souvent la seule culture de rente et la filière coton joue un rôle important dans la lutte contre la pauvreté. Par conséquent, les Institutions de Bretton Woods préconisent des réformes tendant à la mise en place d'un système moins centralisé qui offre une entrée libre dans le secteur de l'égrenage du coton et instaure la concurrence dans l'achat du coton-graine. Ceci aurait pour effet de relever le niveau d'efficacité et de réduire à la fois les coûts et les marges dans ce secteur, ce qui permettrait aux agriculteurs de recevoir un part plus importante des prix à l'exportation'.

Dans le présent document, nous examinons i) les facteurs qui sous-tendent la baisse des cours mondiaux et leurs retombées sur la croissance à long terme des filières coton dans les pays d'Afrique de l'Ouest et du Centre et ii) les réformes nécessaires pour renforcer la compétitivité des filières coton dans ces pays et leur permettre de faire face à l'avenir à une conjoncture semblable sur les marchés internationaux. En particulier, des progrès supplémentaires sont nécessaires afin de renforcer la concurrence et le libre accès à tous les principaux sous-secteurs de cette filière. Nous examinons aussi les conséquences des subventions massives et - dans le cas des États-Unis - en accroissement rapide, que les pays développés et les pays en développement d'Europe et d'Asie accordent à leurs producteurs de coton. Tout en insistant sur la nécessité pour les pays africains de mettre en place des systèmes qui garantissent aux agriculteurs une part plus importante du prix mondial

${ }^{1}$ Il s'agit des pays producteurs de coton suivants : le Bénin, le Burkina Faso, le Cameroun, la Côte d'Ivoire, le Mali, la République centrafricaine, le Sénégal, le Tchad et le Togo. Les pays d'Afrique de l'ouest et d'Afrique centrale non membres de la zone franc (Ghana, Guinée, Nigéria) parce que leurs filières coton sont organisées différemment ou les petits producteurs de la zone franc (Guinée Bissau, Niger) n'entrent pas dans le cadre de la présente étude.

${ }^{2}$ Compte tenu de son expertise dans cette filière, la Banque mondiale a pris l'initiative d'imprimer une orientation à la réforme de la filière coton dans les pays d'Afrique de l'Ouest et du Centre. Toutefois, les programmes du FMI comprennent aussi des réformes de la filière coton de ces pays, où ils jouent un rôle de premier plan dans le maintien de la stabilité macroéconomique. 
et parallèlement en faisant en sorte que la filière soit moins vulnérable aux fluctuations sur les marchés à l'exportation et, partant, moins tributaires de l'intervention de l'État. Nous soulignons combien il importe que les autres pays - en particulier les États-Unis, la Chine et des pays membres de l'Union européenne, réduisent considérablement voire éliminent leur soutien aux producteurs de coton. En effet, l'abolition des subventions octroyées à ces pays supprimerait les incitations à la surproduction qui déplace actuellement les exportations des pays africains et freine davantage la croissance de la filière coton et, partant, la capacité à faire reculer la pauvreté dans les pays d'Afrique de l'Ouest et du Centre.

Le présent document n'a pas pour objet d'analyser en profondeur les problèmes de politique et d'ordre institutionnel ni les difficultés de croissance à long terme auquel fait face la filière coton en Afrique de l'Ouest et du Centre. Cet exercice relève d'une étude séparée effectuée par l'équipe de la Banque mondiale chargée du développement rural. La présente note a pour objet de présenter le point de vue du FMI et de la Banque mondiale sur les principales questions de politique internationale et nationale relatives à la filière coton et de donner des conseils sur les stratégies de réformes aux services de ces deux institutions chargés de ce secteur.

\section{B. Contexte international}

\section{Production mondiale et structures des échanges commerciaux}

Le marché mondial du coton est caractérisé par une production dispersée (bien que ce soit principalement le cas dans l'hémisphère Nord) et d'un volume important du commerce de coton fibre. Bien que la part du coton dans les textiles ait diminué au fil du temps au profit des fibres synthétiques, le coton demeure de loin la fibre la plus importante au monde, avec une part de marché d'environ $40 \%$. Les principaux producteurs, sont, par ordre de grandeur décroissante: la Chine, les États-Unis, l'Inde, le Pakistan et l'Ouzbékistan. Pris ensemble, les pays d'Afrique de l'Ouest et du Centre sont de petits producteurs mais ils sont tout de même importants car, lors de la dernière campagne de récolte, ils ont représenté environ $5 \%$ de la production mondiale (Tableau 1) et $15 \%$ des exportations.

\section{Politiques mondiales relatives à la production et au commerce du coton}

La plupart des principaux producteurs de la région Afrique de l'Ouest et du Centre ont en place des programmes de soutien de la production cotonnière. En 1998/99 et en 1999/00 ces programmes existaient déjà dans les huit pays suivants, représentant environ $53 \%$ de la production mondiale : Brésil, Chine, Égypte, Espagne, États-Unis, Grèce, Mexique et Turquie $^{3}$. Pour la campagne $1998 / 99$, le niveau d'assistance que la filière coton a reçue des gouvernements de ces huit pays s'est élevé à 5,4 milliards de dollars EU. L'année suivante,

\footnotetext{
${ }^{3}$ Voir Carlos Valderrama Becerra, «The World Cotton Market : Prices and Distortions»,
} Conseil consultatif international sur le coton, Washington, 2000. 
Tableau 1. Principaux pays producteurs - Production et exportations nettes de coton, 1980/81-2001/02

(En milliers de tonnes métriques)

\begin{tabular}{|c|c|c|c|c|c|c|c|c|}
\hline & $1980 / 81$ & $1985 / 86$ & 1990/91 & $1995 / 96$ & $1998 / 99$ & $1999 / 00$ & $2000 / 01$ & $2001 / 02$ \\
\hline & & & & & & & & Proj. \\
\hline & \multicolumn{8}{|c|}{ Production } \\
\hline Chine, Rép. pop. de & 2.703 & 4.142 & 4.513 & 4.774 & 4.513 & 3.837 & 4.425 & 5.123 \\
\hline États-Unis & 2.425 & 2.928 & 3.380 & 3.902 & 3.034 & 3.699 & 3.747 & 4.374 \\
\hline Inde & 1.323 & 1.967 & 1.991 & 2.886 & 2.774 & 2.655 & 2.376 & 2.572 \\
\hline Pakistan & 715 & 1.218 & 1.640 & 1.788 & 1.373 & 1.875 & 1.788 & 1.744 \\
\hline Ouzbékistan & 1.671 & 1.730 & 1.595 & 1.251 & 1.003 & 1.129 & 959 & 1.046 \\
\hline Union européenne & 676 & 756 & 945 & 1.337 & 1.334 & 1.365 & 1.321 & 1.401 \\
\hline Afrique de l'Ouest et du Centre $1 /$ & 214 & 364 & 536 & 683 & 878 & 848 & 701 & 959 \\
\hline Brésil & 623 & 831 & 701 & 390 & 458 & 676 & 894 & 719 \\
\hline Autres & 3.491 & 3.565 & 3.680 & 3.269 & 3.061 & 2.942 & 3.083 & 2.989 \\
\hline \multirow[t]{2}{*}{ Monde } & 13.841 & 17.501 & 18.981 & 20.280 & 18.428 & 19.026 & 19.294 & 20.928 \\
\hline & \multicolumn{8}{|c|}{ Exportations nettes } \\
\hline Chine, Rép. pop. de & -773 & 610 & -278 & -659 & 70 & 344 & 47 & -65 \\
\hline États-Unis & 1.286 & 420 & 1.698 & 1.584 & 850 & 1.450 & 1.471 & 2.134 \\
\hline Inde & 119 & 77 & 154 & 105 & -68 & -334 & -327 & -382 \\
\hline Pakistan & 324 & 685 & 295 & 286 & .199 & -13 & 27 & -87 \\
\hline Ouzbékistan & 1.448 & 1.487 & 1.173 & 985 & 830 & 893 & 740 & 718 \\
\hline Union européenne & -715 & -1.071 & -827 & -725 & .783 & -1.021 & -871 & -923 \\
\hline Afrique de l'Ouest et du Centre1/ & 185 & 336 & 440 & 600 & 778 & 816 & 689 & 818 \\
\hline Brésil & 6 & 24 & 67 & -363 & -296 & -335 & -82 & -207 \\
\hline \multicolumn{9}{|l|}{ Pour mémoire : } \\
\hline Exportations mondiales & 5.721 & 6.117 & 6.441 & 6.051 & 5.142 & 5.952 & 5.755 & 6.206 \\
\hline
\end{tabular}

Source : Comité consultatif international sur le coton.

1/ Zone franc uniquement.

l'Égypte a réduit ses subventions de prix, mais les sept autres pays ont maintenu les leurs. Plus de $40 \%$ du soutien a été accordé par les États-Unis (Tableau 2). Ces subventions élevées constituent la principale source des pressions qui s'exercent sur les prix mondiaux (Graphique 1).

L'Union européenne accorde une assistance plus massive aux producteurs de coton, soit plus de $100 \%$ des prix mondiaux. En outre, comparées à d'autres cultures, les subventions accordées à la filière coton de l'Union européenne sont exceptionnellement généreuses. Elles sont trois à quatre fois supérieures par hectare pour le maïs et les oléagineux et sept à huit fois pour les céréales. Toutefois, la production (limitée à la Grèce et l'Espagne), est beaucoup plus faible qu'en Chine ou aux États-Unis. Le système de subventions du coton dans le cadre de la Politique agricole commune a été modifié en 1999 pour accroître les pénalités qui frappent les excédents de production. La Chine fournit une aide considérable aux producteurs de coton par le biais d'un système des prix de référence pour le coton. Actuellement, l'achat et la commercialisation du coton sont monopolisés par le gouvernement et les prix d'achat et de vente sont déterminés largement de manière à 
Tableau 2. Assistance accordé aux principaux pays producteurs de coton, 1999/00

\begin{tabular}{|c|c|c|c|}
\hline \multirow[b]{2}{*}{ Pays } & \multirow{2}{*}{$\begin{array}{c}\text { Production } \\
\text { Milliers de tonnes }\end{array}$} & \multicolumn{2}{|c|}{ Assistance } \\
\hline & & Dollars EU le kilo & Million de dollars EU \\
\hline Total & 9.942 & $0,57 \quad 1 /$ & 4.764 \\
\hline États-Unis & 3.694 & 0,56 & 2.056 \\
\hline Chine, Rép. pop. de & 3.829 & 0,34 & 1.534 \\
\hline Union europeenne & 558 & 1,42 & 795 \\
\hline Grèce & 428 & 1,39 & 596 \\
\hline Espagne & 130 & 1,53 & 199 \\
\hline Turquie & 791 & 0,36 & 287 \\
\hline Brésil & 700 & 0,06 & 44 \\
\hline Mexique & 135 & 0,21 & 28 \\
\hline $\begin{array}{l}\text { Égypte } \\
\text { Pour memoire: }\end{array}$ & 235 & 0,09 & 20 \\
\hline Cours mondial du coton & & 1,25 & \\
\hline
\end{tabular}

Source : Comité consultatif international sur le coton.

l/ Moyenne.

Graphique 1. Prix nominal, prix réel et stocks mondiaux de coton, janvier 1985 -décembre 2002 //

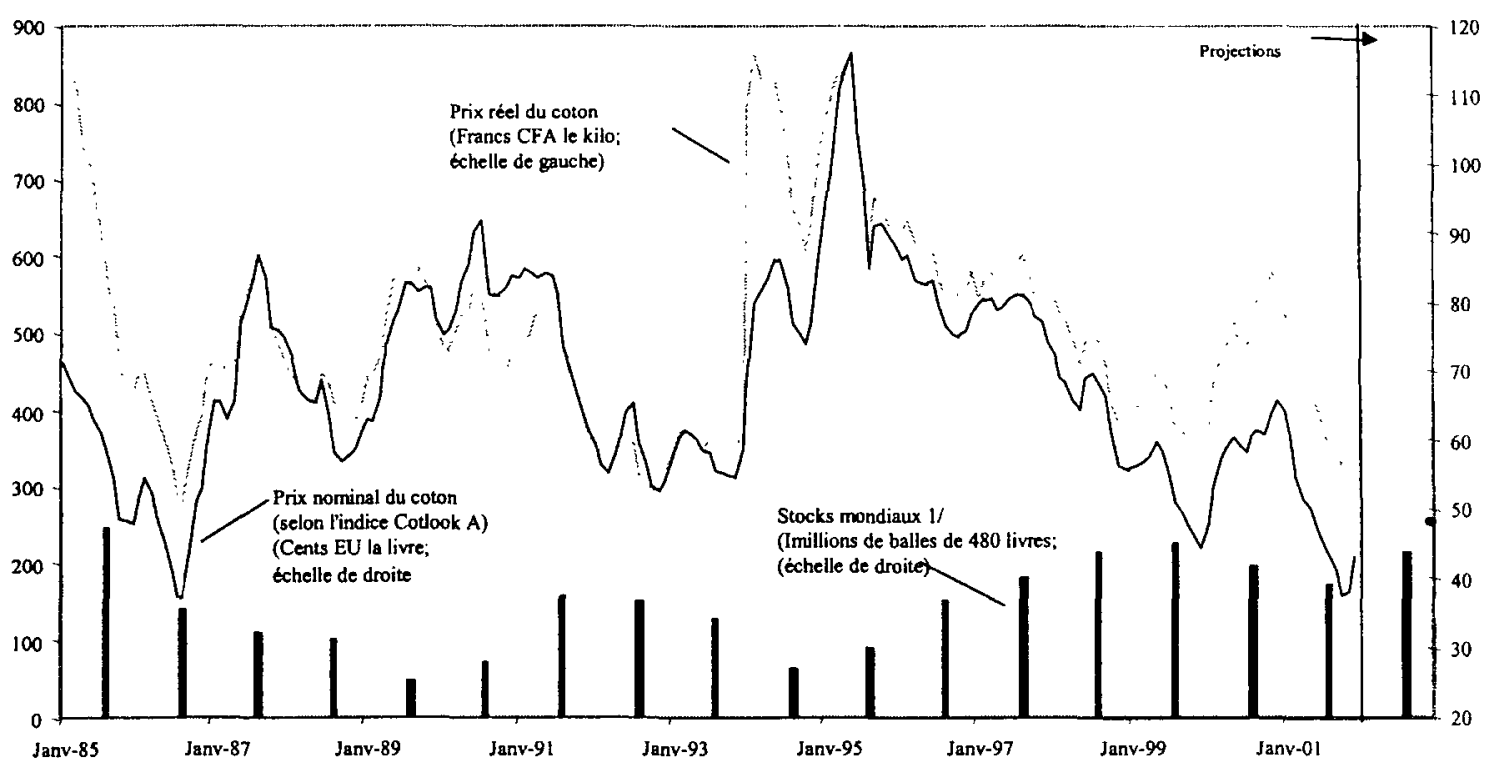

Sources : Département d'agriculture des États-Unis; estimations des services du FMI.

1/ Stocks communiqués en août, dernier mois de la campagne de commercialisation du coton. Prix réel du coton par rapport à l'TPC de l'UEMOA, l'année de base étant 1990. 
subventionner les agriculteurs. Après l'admission de la Chine à l'OMC, le monopole de commercialisation détenu par l'État sera progressivement éliminé et les prix intérieurs devraient se rapprocher des cours mondiaux. Aux États-Unis, le programme d'appui à l'agriculture retient l'attention parce qu'il part de l'hypothèse que les prix agricoles resteraient stables ou qu'ils qu'ils enregistreraient une légère hausse. Dans un premier temps, il avait donc pour objectif de renforcer le rôle joué par les forces du marché dans les décisions de production lorsqu'il a été conçu en 1996. Avec l'expansion de la production et l'amorce de la chute des prix, le niveau des subventions a considérablement augmenté. Au lieu de faciliter l'ajustement de la production à l'offre excédentaire et à la baisse des prix, les subventions de prix octroyés aux Etats-Unis se sont soldées par un accroissement de la production le coton étant devenu plus rentable que les denrées concurrentes telles que les fèves de soja, le maïs ou le sorgho ${ }^{4}$. Par exemple, les producteurs de coton américains sont censés recevoir davantage d'incitations au cours de la campagne actuelle qu'en 1999, année au cours de laquelle les cours du coton étaient aussi très bas ${ }^{5}$.

Les programmes de subventions des produits agricoles devraient être renouvelés avant la fin de l'exercice budgétaire en cours en septembre $2002^{6}$. Les propositions contenues dans la loi sur l'agriculture visant à renouveler ces programmes dont le Congrès est actuellement saisi auraient essentiellement pour effet de: i) maintenir en place un niveau de dépenses qui a été gonflé artificiellement au cours des dernières années par les mesures de financement «d'urgence», ii) introduire un nouveau facteur anti-conjoncturel lié au prix des produits et iii) élargir la couverture des programmes à d'autres produits agricoles. La nouvelle proposition de loi sur l'agriculture contribuerait à la poursuite de la surproduction et à l'effondrement des cours mondiaux des produits agricoles couverts par les programmes de soutien, notamment le coton, perpétuant ainsi les problèmes auxquels font face les exportateurs des pays d'Afrique de l'Ouest et du Centre.

${ }^{4}$ Les agriculteurs américains bénéficient d'un certain nombre de programmes publics : des contrats de flexibilité de la production et des programmes de prêts pour la mise en valeur des produits de base, l'assurance subventionnée des récoltes et des recettes et une assistance en cas de pertes sur le marché. Aux États-Unis, les politiques américaines ont conduit à un découplage du prix du coton que les agriculteurs reçoivent du cours mondial. Malgré le fait que les cours du coton sont aujourd'hui à leur niveau le plus bas, les prix versés aux agriculteurs américains se sont en réalité accrus depuis le début 2001, dès lors qu'on y inclut la valeur des programmes de prêts (comme subvention par unité).

${ }^{5}$ Voir Leslie Meyer et Stephen MacDonald, «Cotton Background and Issues for Farm Legislation», Ministère de l'agriculture des États-Unis, Service de la recherche économique, juillet 2001.

${ }^{6}$ Pour de plus amples détails, voir le document de synthèse préparé en vue de consultations de 2001 avec les Etats-Unis au titre de l'Article IV : «Recent Changes in U.S. Agricultural Support Policy and Their Impact on Other Countries» (IMF, SM/01/213). 


\section{LA FILIÈre COTON EN AFRIQUe de L'OUEST ET du CENTRE}

Dans la présente section nous faisons le point sur la situation que traversent actuellement les des filières coton de la région avant d'aborder, dans la section suivante, le programme de réformes. Bien que la production cotonnière se soit accrue rapidement, la part des prix internationaux versée aux producteurs est relativement faible du fait des faiblesses que présentent les sous-secteurs de l'égrenage, de la commercialisation, et de la distribution des intrants. Une transition vers le renforcement de la concurrence et de la transparence et, partant, vers une efficacité accrue dans la transformation et la commercialisation du coton permettraient aux pays d'Afrique de l'Ouest et du Centre d'accroître davantage la production et leurs parts de marché à l'exportation.

\section{Production et résultats du secteur de l'égrenage}

La production cotonnière des pays d'Afrique de l'Ouest et du Centre a quadruplé depuis le début des années 1980 (Graphique 2). Le coton s'est révélé comme une culture économiquement viable qui a influé très positivement sur les exportations, la croissance économique et le développement rural. L'égrenage de coton, l'offre d'intrants, le transport et la commercialisation constituent des activités économiques importantes dans la plupart de ces pays. Les activités liées au coton représentent une part importante des emplois et des exportations dans les zones rurales et sont à l'origine d'une part importante des recettes publiques. À l'exception du Bénin, la production cotonnière a stagné, voire reculé dans les pays d'Afrique de l'Ouest et du Centre au cours des six dernières années qui ont précédé la dévaluation du franc CFA en 1994 et s'est accélérée après la dévaluation (Tableau 3). La production s'est accrue de $16 \%$ par an en moyenne de 1993/94 à 1997/98 puis elle s'est tassée pendant trois années consécutives avant d'atteindre un nouveau record en 2001/02. Au cours des quatre dernières années, la production a sensiblement augmenté au Mali, en Côte d'ivoire, au Burkina Faso et au Cameroun. Elle a légèrement reculé au Bénin et considérablement diminué au Tchad et au Togo.

Le développement de cette filière a permis de produire un coton systématiquement de bonne qualité, d'enregistrer des rendements agricoles moyens élevés (selon les normes internationales) et des ratios d'égrenage élevés. En 1995/96, les rendements agricoles se sont situés dans la fourchette de 1000 à $1200 \mathrm{~kg} / \mathrm{ha}$, excepté au Burkina Faso et au Tchad où ils ont été inférieurs à $1000 \mathrm{~kg} /$ ha Les ratios d'égrenage, à environ 40-43\%, sont aussi élevés dans les pays d'Afrique de l'Ouest et du Centre par rapport aux normes internationales. En revanche, ils sont plus proches de $34-36 \%$ pour le coton de nature similaire en Inde, et au Zimbabwe ils sont environ de l'ordre de $39 \%$. Plusieurs facteurs ont contribué au succès de la production cotonnière dans la région : reconstitution des sols en éléments nutritifs, lutte contre les parasites, et variétés de semences bien adaptées aux conditions locales; offre de services d'appui et d'infrastructure par le gouvernement et par les sociétés cotonnières; prix garantis à la production et marchés d'écoulement de la production; taux de recouvrement des crédits alloués pour l'achat d'intrants et associations villageoises bien organisées. 
Tableau 3. Pays d'Afrique de l'Ouest et du Centre - Production et exportations nettes de coton , 1980/81-2001/02

(En milliers de tonnes métriques)

\begin{tabular}{|c|c|c|c|c|c|c|c|c|c|}
\hline & 1980/81 & $1985 / 86$ & $1990 / 91$ & 1993/94 & $1997 / 98$ & $1998 / 99$ & $1999 / 00$ & $2000 / 01$ & $2001 / 02$ \\
\hline & & & & & & & & & Proj. \\
\hline & \multicolumn{9}{|c|}{ Production } \\
\hline Bénin & 4 & 32 & 59 & 116 & 152 & 142 & 150 & 131 & 136 \\
\hline Burkina Faso & 23 & 46 & 77 & 51 & 138 & 120 & 110 & 114 & 164 \\
\hline Cameroun & 32 & 46 & 44 & 51 & 76 & 78 & 75 & 94 & 95 \\
\hline Côte d'Ivoire & 56 & 82 & 116 & 114 & 147 & 157 & 164 & 125 & 164 \\
\hline Mali & 43 & 68 & 115 & 101 & 216 & 218 & 196 & 105 & 240 \\
\hline République centrafricaine & 8 & 13 & 12 & 7 & 20 & 16 & 11 & 9 & 11 \\
\hline Sénégal & 7 & 11 & 12 & 15 & 17 & 5 & 9 & 9 & 14 \\
\hline Tchad & 31 & 39 & 60 & 37 & 109 & 65 & 76 & 65 & 76 \\
\hline \multirow[t]{2}{*}{ Togo } & 9 & 27 & 41 & 33 & 65 & 76 & 57 & 49 & 60 \\
\hline & \multicolumn{9}{|c|}{ Exportations nettes } \\
\hline Bénin & 6 & 27 & 50 & 105 & 141 & 131 & 142 & 136 & 125 \\
\hline Burkina Faso & 21 & 44 & 69 & 44 & 120 & 114 & 113 & 113 & 147 \\
\hline Cameroun & 27 & 38 & 34 & 37 & 63 & 65 & 65 & 81 & 82 \\
\hline Côte d'Ivoire & 43 & 84 & 81 & 80 & 98 & 120 & 160 & 109 & 131 \\
\hline Mali & 38 & 60 & 98 & 87 & 174 & 202 & 196 & 125 & 196 \\
\hline République centrafricaine & 5 & 11 & 9 & 3 & 17 & 15 & 10 & 8 & 9 \\
\hline Sénégal & 4 & 7 & 7 & 11 & 11 & 2 & 3 & 4 & 8 \\
\hline Tchad & 33 & 44 & 57 & 33 & 101 & 63 & 72 & 65 & 65 \\
\hline Togo & 7 & 22 & 36 & 35 & 57 & 65 & 55 & 47 & 55 \\
\hline
\end{tabular}

Source : Comité consultatif international sur le coton.

Graphique 2

Production cotonnière de $\mathrm{b}$ zone franc et du reste de

l'Afrique subsaharienne, 1980-2001

(milliers de tonnes métriques)

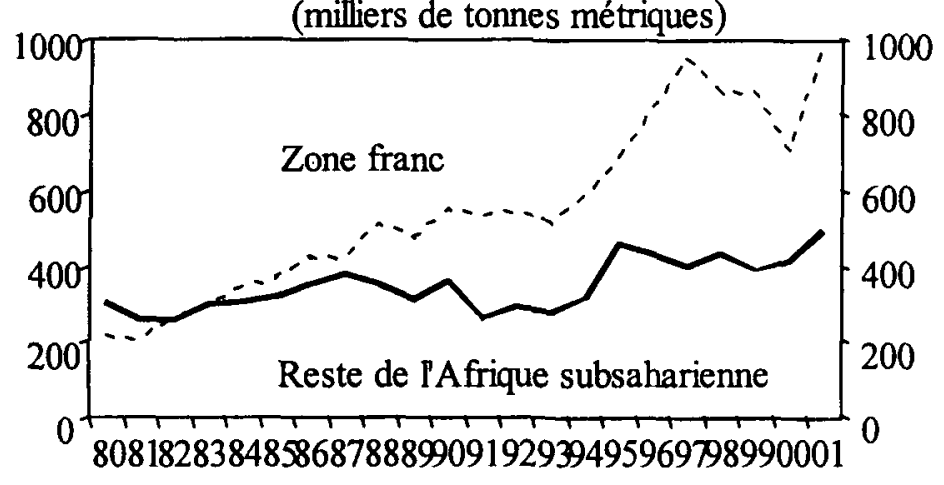

Source : Comité consultatif intemational sur le coton. 


\section{Environnement institutionnel}

En dépit des résultats traditionnellement bons enregistrés par cette filière, l'environnement institutionnel dans lequel elle évolue a été à l'origine de nombreuses carences, ce qui permet d'affirmer qu'il subsiste une importante marge de progression. Ainsi, à l'exception du Bénin et de la Côte d'Ivoire, la filière coton reste sous le contrôle d'une seule société qui a la mainmise sur l'offre d'intrants et d'autres services aux agriculteurs et qui détient le monopole de l'achat de la récolte cotonnière. À l'exception du Burkina Faso, les gouvernements sont des actionnaires majoritaires de ces sociétés. Le manque de transparence qui règne dans ces systèmes de monopole administré crée de nombreuses possibilités de rentes de situation et conduit à une mauvaise gestion de ressources, généralement aux dépens des agriculteurs, du budget national et de l'économie dans son ensemble ${ }^{7}$. En particulier, il limite strictement les incitations octroyées afin de réduire autant que possible les coûts et étouffe le processus de décision d'investissement à tous les niveaux de la chaîne de l'offre.

Il importe de souligner que la viabilité des filières nationales dans le cadre des systèmes actuels repose avant tout sur leur aptitude à i) imposer les producteurs et à accumuler les bénéfices lorsque les prix à l'exportation sont élevés et ii) à compter sur le soutien budgétaire accordé par les gouvernements lorsque les cours internationaux sont déprimés. Cette stratégie n'a pas bien fonctionné dans de nombreux pays à cause de la mauvaise gestion des fonds de péréquation par les responsables des monopsones cotonniers. Il convient de la changer en ces temps de mondialisation et d'intégration régionale accrues. Le fait que les deux organisations de producteurs deviennent de plus en plus fortes ne permet plus tout à fait de continuer d'imposer les producteurs. De même, la pression accrue qui s'exerce sur les ressources budgétaires limitera la capacité des gouvernements à sauver des entreprises parapubliques nationales lors des crises à venir.

Le système de détermination des prix en vigueur actuellement garantit une certaine stabilité aux agriculteurs mais à un coût élevé en termes de manque à gagner au titre des recettes et de diminution du potentiel de croissance à long terme. Le tableau ci-dessous montre l'incidence du système en vigueur actuellement sur la détermination des prix dans chacun des pays d'Afrique de l'Ouest et du Centre ${ }^{8}$. Avant la dévaluation du franc CFA survenue en 1994, les

${ }^{7}$ Diverses études diagnostiques de la filière coton et des audits techniques des sociétés cotonnières effectués dans de nombreux pays au fil des années ont, de manière répétée, fait apparaitre un nombre considérable de situations de rentes et des coûts d'exploitation relativement élevés dans le secteur de l'égrenage. Les exemples les plus récents sont l'audit technique de la CMDT réalisé au Mali en 2000 et l'enquête sur les coûts d'égrenage au Bénin de 2001.

${ }^{8}$ Cette différence de ratio d'un pays à l'autre s'explique en partie par le fait que les coûts de transport des usines d'égrenage aux ports maritimes sont plus élevés dans les économies enclavées. 
Tableau 4. Coton-fibre - Ratio des prix intérieurs à la production sur le cours mondial l/

\begin{tabular}{lrrrrrrrr}
\hline & Bénin & $\begin{array}{r}\text { Burkina } \\
\text { Faso }\end{array}$ & Cameroun & Tchad & $\begin{array}{c}\text { Côte } \\
\text { d'Ivoire }\end{array}$ & Mali & Togo $\begin{array}{r}\text { Moyenne } \\
\text { des pays }\end{array}$ \\
\hline $1988 / 89-1993 / 94$ & 52 & 54 & 48 & 48 & 51 & 46 & 49 & 50 \\
$1994 / 95-1996 / 97$ & 41 & 39 & 38 & 35 & 41 & 36 & 40 & 39 \\
$1997 / 98-2000 / 01$ & 59 & 51 & 50 & 49 & 55 & 48 & 57 & 53 \\
\hline
\end{tabular}

Sources : Les données sur les prix à la production sont tirées de Pursell, "Cotton Policies in Francophone Africa", exposé présenté à un séminaire de la Banque mondiale, Mai 2001; les séries sur les cours intemationaux sont extraites de la base des données des Perspectives de l'économie mondiale du FMl; et les récents prix à la production ont été communiqués par les économistes du FMI.

prix à la production dans les pays d'Afrique de l'Ouest et du Centre correspondaient environ à la moitié des cours internationaux. Au cours de la période qui a suivi immédiatement la dévaluation du franc CFA (1994/95-1997/97), les prix à la production dans les pays de la zone franc ont enregistré un net repli par rapport aux cours internationaux en raison des politiques intérieures mises en œuvre délibérément en vue d'assainir les positions budgétaires et de juguler les pressions inflationnistes. Durant la période 1997/98-2000/01, les parts des prix à la production se sont accrues pour atteindre un niveau légèrement supérieur en moyenne à celui d'avant la dévaluation. Néanmoins, ce ratio a été plus élevé dans des pays tels que le Bénin et la Côte d'Ivoire qui étaient relativement plus avancés dans la mise en oeuvre des réformes structurelles au sein de la filière.

Le fossé relativement large qui sépare les prix à la production sur les marchés intérieurs des prix à l'exportation du coton-graine exprimés en équivalent coton-fibre s'explique avant tout par i) le renchérissement des coûts d'exploitation des sociétés cotonnières (Graphique 3); ii) les subventions implicites octroyées à d'autres pans de la filière par les sociétés cotonnières parapubliques (telles que des sociétés privées d'égrenage et des sociétés nationales de production d'huile et de transformation de tourteaux); et iii) l'offre de divers services publics (entretien des infrastructures, offre de services scolaires et sanitaires) par les sociétés cotonnières dans les régions productrices de coton.

Graphique 3. Afrique de l'Ouest et du Centre Ratio des coûts d'exploitation sur le total des coûts $1 /$

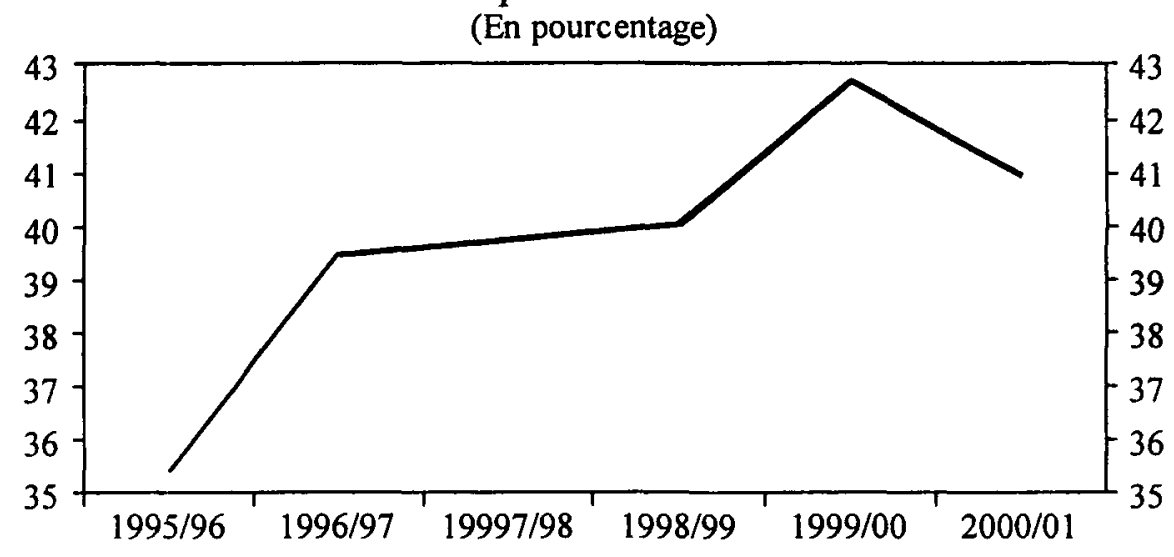

1/ Le rario moyen correspond au Bénin, au Burkina Faso, au Mali et au Tchad Les cô̂ts dexploitation comprennent la totalité des coûts, exception faite du prix dachat du coton-graine. Les coûts sont f.à.b. 


\section{Compétitivité internationale et potentiel de croissance de la filière coton des pays d'Afrique de l'Ouest et du Centre}

La compétitivité de la filière coton de la région se manifeste par le faible niveau des cours comparés à d'autres pays et par la ferme croissance la production enregistrée au cours des deux dernières décennies. Il est difficile de comparer les coûts de production des différents producteurs de coton du monde étant donné que les données dont nous disposons sont incomplètes. La source la plus fiable est le Comité consultatif international sur le coton (CCIC), qui a effectué une enquête sur le coût de production du coton brut en 2001/2002 dans 28 pays, y compris les principaux producteurs (Chine, États-Unis, Inde, Ouzbékistan et Pakistan), et quatre pays d'Afrique de l'Ouest et du Centre et six autres pays d'Afrique subsaharienne. S'il convient, de souligner que même ces données sont imparfaites, il apparaît, toutefois, que les pays d'Afrique de l'Ouest et du Centre figuraient parmi ceux dont les coûts de production sont les moins élevés au monde. Le tassement actuel des cours mondiaux témoigne du niveau de compétitivité de la filière coton dans les pays d'Afrique de l'Ouest et du Centre. Certes, il a fallu octroyer des subventions de l'ordre de 50 à 60 millions de dollars EU pour la zone dans son ensemble afin d'amortir l'impact de l'effondrement des cours mondiaux; toutefois, les filières coton nationales auraient été rentables si le cours international du coton avait excédé 50 cents la livre. Ils sont très peu, les autres pays qui peuvent produire du coton de manière rentable à ce niveau de prix.

Les pays d'Afrique de l'Ouest et du Centre peuvent produire du coton économiquement et en règle générale, le coton est de loin plus rentable que d'autres cultures pratiquées partout ailleurs dans la région. Bien que les agriculteurs puissent passer relativement aisément de la culture du coton à celle des graines de soja aux États-Unis, en Australie ou au Brésil en fonction des prix relatifs, les agriculteurs de nombre de pays d'Afrique de l'Ouest et du Centre ont une marge de substitution beaucoup plus limitée. Au Burkina Faso, le principal choix se pose en termes de formule mixe coton/maïs ou niébé tout seul. Comme le montre le Tableau 2 ci-dessus, la production du coton dans la plupart des pays concurrents est massivement subventionnée. Les agriculteurs des deux principaux pays producteurs qui représentent quasiment la moitié de la production mondiale ont bénéficié de subventions jusqu'à hauteur de $20 \%$ des cours mondiaux dans le cas de la Chine et de $50 \%$ dans le cas des États-Unis tandis que les subventions octroyées par l'Union européenne ont excédé $100 \%$. Les producteurs de la région Afrique de l'Ouest et du Centre sont actuellement les principaux perdants du fait des politiques en vigueur niveau international étant donné qu'ils sont pénalisés à la fois sur le plan intérieur par le biais de la fiscalité implicite et sur les marchés internationaux par les subventions en place chez leurs concurrents. Par conséquent, il ne fait pas de doute que les producteurs des pays d'Afrique de l'Ouest et du Centre bénéficieraient considérablement de la production cotonnière dans un environnement international qui présenterait moins de distorsions.

D'après les estimations établies sur la base du modèle de la demande mondiale de textiles mis au point par le Comité consultatif international sur le coton (CCIC), la suppression des subventions aux États-Unis entraînerait une chute de la production américaine qui 
provoquerait une hausse du cours mondial à court terme de l'ordre de 12 cents la livre. ${ }^{9}$ Un renchérissement du cours mondial du coton de cette ampleur augmenterait les recettes cotonnières d'environ 250 millions de dollars dans les pays d'Afrique de l'Ouest et du Centre. Ce chiffre est à comparer au total des flux d'APD vers la région qui s'est élevé à 1,8 milliard de dollars en 1999 et aux 50 à 60 millions de dollars de subventions octroyées aux agriculteurs d'Afrique de l'Ouest et du Centre au cours de la présente campagne pour les prémunir de l'effondrement des cours. L'abolition des subventions octroyées par les pouvoirs publics aux États-Unis et en Chine, de loin les principaux producteurs du monde, et le plus grand exportateur mondial dans le cas des États-Unis, contribuerait à réorienter la production vers les pays où les coûts de production sont moins élevés, y compris en Afrique de l'Ouest et du Centre. Bien que le relèvement des prix à long terme soit plus limité que ne l'indiquent les estimations ci-dessus, en raison des ajustements induits dans la production et la consommation, l'incidence sur la croissance à long terme et sur la réduction de la pauvreté en Afrique serait importante. La réduction de la proportion de la production de coton qui échappe au jeu des forces du marché du fait des subventions octroyées par les pouvoirs publics pourrait aussi contribuer à atténuer la volatilité du cours mondial (libre) du coton. Une stabilité accrue du marché améliorerait l'environnement commercial et encouragerait la production dans les pays exportateurs plus compétitifs tels que ceux de la région Afrique de l'Ouest et du Centre.

\section{PROGRAMME DE RÉFORMES : VERS DES FILIÈRES COTON COMPÉTITIVES}

L'objectif stratégique à long terme de la filière coton est, non seulement de contribuer aux recettes d'exportation et aux recettes publiques mais aussi d'accroître et de soutenir sa contribution à la réduction de la pauvreté par la création d'emplois et de revenus dans les zones rurales. Les recherches effectuées sur les liens avec la croissance en Afrique de l'Ouest ont montré des effets multiplicateurs considérables sur l'emploi et le revenu résultant de l'expansion du revenu tiré des cultures de rente dans le reste de l'économie rurale. Les implications de la croissance durable dans la filière coton ou de son absence sur la réduction de la pauvreté ainsi que la nécessité de mettre en oeuvre des réformes afin matérialiser cette croissance doivent donc être examinées sous un angle beaucoup plus large et non sous l'angle de l'incidence immédiate dans la filière ou des retombées à court terme sur les finances publiques.

Étant donné que les différents pays d'Afrique de l'Ouest et du Centre se trouvent à des stades différents de leur progrès dans la mise en place de filières compétitives, le programme de réforme doit tenir compte de la situation de chaque pays. Dans les sections suivantes, nous présentons des repères en vue de la réforme des différents sous-secteurs de la filière coton qui sont tributaires de l'environnement institutionnel de chaque pays. Nous i) résumons les

\footnotetext{
${ }^{9}$ Becerra, 2000, op.cit. La réduction des subventions dans l'Union européenne devrait avoir des retombées similaires mais beaucoup moins limitées, étant donné que la production concernée est nettement plus faible.
} 
principales caractéristiques des différents sous-secteurs actuels, ii) décrivons les principaux facteurs qui dénoteraient le succès des réformes dans ces secteurs, iii) spécifions les changements d'objectifs à court terme qui doivent être effectués afin d'aller de l'avant dans la mise en place de filières coton nationales compétitives et nous identifions les mesures précises que doivent prendre le gouvernement, les parties prenantes dans le secteur privé, et les partenaires du développement.

Le train de réformes qui est décrit ci-dessous reflète les progrès réalisés en vue d'un consensus sur la base de consultations intensives en cours depuis 1998 entre la Banque et le FMI, le Ministère français de la coopération, les gouvernements, les groupements de producteurs et les sociétés d'égrenage. Ce consensus croissant a été confirmé en juillet 1999 à Ouagadougou au colloque régional sur l'avenir de la filière coton en Afrique de l'Ouest et du Centre. L'une des conclusions importantes de ce colloque est qu'il est nécessaire d'introduire la concurrence à tous les niveaux dans cette filière afin de la rendre plus efficace et de réaliser une croissance durable.

L'expérience montre que pour réussir la réforme de la filière coton afin d'aboutir à la mise en place d'un système compétitif, il faudra y consacrer plusieurs années. La mise en œuvre du plan de réforme doit suivre un enchaînement logique et conduite de manière à limiter les dérèglements qui pourraient être préjudiciables à la production. Toutefois, dans la plupart des cas, les principales les étapes du processus de réforme consisteraient à i) dissocier du secteur privé les activités accessoires des sociétés cotonnières parapubliques (y compris les services de vulgarisation, les activités de transport, l'achat et la distribution d'intrants et d'équipements ainsi que la commercialisation du coton-graine et des semences); ii) renforcer les capacités techniques des associations d'agriculteurs afin qu'elles puissent directement contracter des crédits bancaires par le biais d'un système de recouvrement privé qui établit des liens entre le remboursement des créances et la commercialisation du coton graine et iii) instaurer la concurrence en ouvrant le secteur aux sociétés privées d'égrenage, ce qui, dans la plupart des cas exigerait la privatisation des usines d'égrenage parapubliques. En outre, la commercialisation du coton-fibre doit se faire à travers un processus d'appel d'offres transparents et compétitifs. À court et à moyen terme, il existe une marge de manœuvre considérable pour réduire les coûts d'exploitation des monopsones cotonniers inefficaces.

Il convient d'insister sur le fait que dans le cadre de la mise en œuvre des réformes, les partenaires au développement devraient fournir à ces pays l'assistance technique nécessaire à l'appui des programmes afin de réussir la transition vers des systèmes ouverts et compétitifs. Cette démarche a porté ses fruits au Bénin où le FMI, la Banque mondiale et des donateurs bilatéraux travaillent en collaboration étroite avec le gouvernement et le secteur privé pour faciliter le processus de réforme. La filière coton au Mali bénéficie aussi d'un soutien similaire. Il faudra, d'ailleurs l'étendre à d'autres pays afin de multiplier les chances de succès de la réforme de cette filière. 


\section{Offre de crédits pour l'achat d'intrants}

Le succès de la réforme de ce sous-secteur garantirait le recouvrement efficace des créances tout en favorisant l'émergence d'une politique de commercialisation compétitive du cotongraine. Actuellement, le recouvrement des créances se fait de deux manières. À l'exception d'un seul de ces pays, les sociétés d'égrenage publiques ou privées, servent d'intermédiaires en vue de l'obtention de crédits pour l'achat d'intrants qu'elles recouvrent aussi en lieu et place des banques commerciales ou des négociants. Dans le cas du Bénin qui est l'exception, le recouvrement des créances se fait par le biais d'un mécanisme de type organisation professionnelle et ne fait pas intervenir des sociétés d'égrenage. Bien que ce dernier mécanisme maintienne le lien crucial direct entre le paiement du coton-graine et le recouvrement des créances, il élimine l'intermédiation des sociétés d'égrenage qui, dans le cas de sociétés d'État, a attiré les chercheurs de rentes qui n'ont guère à cour d'investir à long terme dans les activités de distribution d'intrants. En réalité, le système béninois remplace l'intermédiation et la garantie traditionnelle de la société d'État par une série de contrats entre les opérateurs privés impliqués. Par conséquent, la prochaine étape de cette transition doit être la mise en place d'un système efficace de réalisation des contrats afin de préserver l'intégrité de ce nouveau mécanisme. La transition dans le reste des pays se ferait en deux étapes qui pourraient être exécutées simultanément ou de manière séquentielle, à savoir: la réduction des coûts d'intermédiation du crédit et la mise en place d'un système de recouvrement privé, peut-être dans un premier temps, de type association de commercialisation produits agricoles à l'instar du modèle béninois, qui devrait se révéler efficace dans le cadre d'un système compétitif d'agriculture contractuelle.

L'objectif stratégique visé par ce sous-secteur doit être de maintenir un large accès des agriculteurs au crédit en vue de l'achat des intrants à un coût raisonnable en encourageant la mise en place de mécanismes de recouvrement qui soient plus transparents et compatibles avec des systèmes de commercialisation compétitifs du coton-graine. Étant donné que les actifs des agriculteurs sont limités et les marchés financiers sous-développés, ces mécanismes devraient maintenir un lien direct entre le paiement du coton-graine et le recouvrement des créances contractées en vue de l'achat des intrants. Ils fonctionneraient mieux s'ils étaient mis en place et gérés par le secteur privé mais il leur faudra une assistance de la part des gouvernements et de leurs partenaires du développement.

\section{Commercialisation du coton-graine}

La commercialisation du coton-graine devrait être conditionnée par la nécessité de la mise en place d'un mécanisme de recouvrement efficace des créances octroyées pour l'achat d'intrants. L'indicateur du succès des réformes doit donc être l'émergence d'un système de commercialisation qui autorise le libre accès sans pour autant hypothéquer le recouvrement des créances octroyées en vue de l'achat d'intrants. À en juger par l'expérience des pays d'Afrique de l'Ouest et du Centre, un tel système devrait maintenir un lien direct entre le paiement du coton-graine et le recouvrement des créances au titre de l'achat des intrants. La transformation la moins compliquée et la moins risquée remplissant cette condition entraînerait la mise en place d'un système compétitif d'agriculture sous contrat, au moins 
durant les premières années. Dans le cadre de l'agriculture contractuelle, des associations locales d'agriculteurs négocieraient des contrats de prix et de vente, sur une base annuelle ou pluriannuelle, avec une ou plusieurs sociétés d'égrenage. Au titre de ces contrats, les agriculteurs membres pourraient avoir accès aux outils juridiques et institutionnels nécessaires pour résoudre nombre de problèmes de production et de commercialisation auxquels ils font face et qui sont, notamment, la mise au point et la diffusion des technologies, l'accès au crédit, l'achat d'intrants, la qualité des produits et la stabilisation des prix. Par exemple, on pourrait s'appuyer sur les contrats de vente pour garantir les crédits accordés au titre de l'achat d'intrants et les sociétés d'égrenage pourraient collaborer avec des associations locales de producteurs pour souscrire à une assurance et se doter d'autres instruments en vue de stabiliser les prix et les revenus. Afin d'assurer le succès de l'agriculture contractuelle, les capacités techniques des groupements locaux d'agriculteurs devraient être considérablement renforcées pour leur permettre de négocier efficacement et de faire respecter les contrats conclus avec les sociétés d'égrenage ainsi que d'autres opérateurs privés, y compris les banques commerciales et les distributeurs d'intrants.

Actuellement, il existe dans la région trois systèmes de commercialisation du coton-graine. Le premier, qui est le plus courant dans tous ces pays, à l'exception du Bénin et de la Côte d'Ivoire, correspond au modèle traditionnel où une seule société détient le monopole. Le second système est celui en vigueur en Côte d'Ivoire où le monopole traditionnel au niveau national a été remplacé par trois monopoles géographiques. Le troisième système est celui en place au Bénin où le monopole de la société nationale de coton a été levé, et les décisions concernant les prix et la commercialisation sont négociées entre opérateurs privés au niveau national. Dans ces trois cas où il existe plusieurs sociétés d'égrenage (Bénin, Côte d'Ivoire et Togo), le prix du coton-graine est dissocié de la répartition des quantités de coton-graine entre ces sociétés. Dans le cas du Bénin et du Togo, la répartition du coton-graine s'effectue sur la base de la part des capacités d'égrenage installées. En Côte d'Ivoire, la quantité de coton-graine qu'une société reçoit est en principe fonction du niveau de production au sein de sa zone géographique concernée. Dans tous ces cas, le système en vigueur ne permet pas la concurrence entre sociétés d'égrenage pour ce qui est du coton-graine. En outre, il pénalise les usines d'égrenage efficaces et récompense les moins efficaces.

Le choix d'un système d'agriculture sous contrat permettrait de décentraliser les prix et d'éliminer la répartition administrative du coton-graine et encouragerait la concurrence entre sociétés d'égrenage. Toutefois, il faudrait pour cela renforcer les capacités organisationnelles, techniques et commerciales des associations de producteurs qui, actuellement, se trouvent à un stade embryonnaire. Par conséquent, la prochaine étape de la transition qui devrait aller de pair avec le renforcement des capacités des groupements de producteurs devrait être la mise en place de mécanismes privés de négociation des décisions de prix et de commercialisation. Cette démarche doit s'accompagner de l'élimination de monopoles géographiques dans le cas de la Côte d'Ivoire et de l'abolition du monopole des sociétés nationales sur la commercialisation du coton-graine dans le reste des pays et de la mise en place de mécanismes privés de recouvrement des créances accordées au titre de l'achat d'intrants. Au Bénin, la prochaine étape devrait être la décentralisation du processus de négociation. Dès lors que les capacités des groupements locaux de producteurs auront été 
suffisamment renforcées, les filières pourraient passer à l'adoption de systèmes où les sociétés d'égrenage négocient des décisions de prix et de commercialisation directement avec les groupements locaux de producteurs.

Dans le cadre de la réforme des systèmes de commercialisation intérieures, il est important d'éliminer les barrières au commerce transfrontalier de coton-graine. Tous les pays producteurs de coton évoqués dans le présent document sont membres de deux organismes d'intégration régionale ayant adopté des politiques visant à créer des marchés communs régionaux en Afrique de l'Ouest et du Centre. En outre, le coton est une denrée échangeable importante et, le fait de permettre le commerce transfrontalier renforcerait la concurrence sur le marché du coton-graine, améliorerait le revenu des producteurs et créerait des incitations en faveur de l'investissement dans cette filière.

\section{3. Égrenage du coton}

Actuellement, le secteur de l'égrenage est caractérisé par deux modes d'organisation: l'un est fondé sur le système où une seule société détient le monopole et l'autre sur la coexistence administrée de sociétés publiques et privées. Dans les pays où une seule société détient le monopole, l'étape qui suit immédiatement doit prévoir trois mesures : i) ouvrir le secteur et admettre de nouveaux participants, ii) s'assurer que les sociétés nationales réduisent les coûts unitaires en rationalisant les opérations d'égrenage et en séparant les activités accessoires telles que le transport et les huileries et iii) maximiser les recettes en vendant les semences à des prix compétitifs et en souscrivant à des accords efficaces d'exportation de fibres. Dans les pays où il existe déjà des sociétés privées d'égrenage, la prochaine étape du processus de transition devrait être de renforcer la concurrence entre les sociétés d'État et les entreprises privées afin de l'aligner sur les réformes mises en œuvre dans les secteurs de la commercialisation des intrants et du coton-graine. À ce stade, les pays doivent ouvrir les marchés régionaux du coton-graine et permettre aux sociétés d'égrenage de rivaliser entre elles sur le marché régional du coton graine, ce qui aurait pour effet d'encourager les sociétés d'égrenage à être plus efficaces.

Le secteur de l'égrenage est l'une des principales causes des carences constatées dans la chaîne de l'offre, ce qui explique l'importance stratégique que revêt la promotion de la concurrence et, partant, le renforcement de l'efficacité de ce sous-secteur. Au-delà du cadre réglementaire créé en vue de l'application des contrats mentionné dans les sections précédentes, les gouvernements devront promouvoir l'accès de nouveaux opérateurs ainsi que la concurrence en privatisant les sociétés nationales, de préférence, sous forme d'entités distinctes afin d'éviter la formation de monopoles privés. Les concours attendus des donateurs comprendraient l'aide en vue de la planification et de la mise en oeuvre des processus de privatisation et le renforcement des capacités nationales d'application des contrats. 


\section{Importations et distribution d'engrais et de pesticides}

Le succès des réformes mises en œuvre dans les sous-secteurs des engrais et des pesticides devraient se traduire par la mise en place de systèmes d'importation et de distribution privés compétitifs. Il existe actuellement trois types de structures institutionnelles différents correspondants aux cas suivants: i) la société nationale détient le monopole d'achat et de distribution; ii) la société nationale importe par le biais d'importateurs privés mais demeure en charge du processus de distribution; et iii) une organisation professionnelle organise le processus d'achat au nom des agriculteurs mais l'importation et la distribution sont assurées par des opérateurs privés. Pendant la transition, on pourrait envisager que les pays passent progressivement de la première à la troisième structure. Ce faisant, dans les pays où la société nationale directement chargée de l'importation et de la distribution, la prochaine étape à franchir immédiatement devrait être d'opter pour un système où la société importe par l'intermédiaire de négociants privés. Ensuite, il faudrait mettre en place un mécanisme de type organisation professionnelle qui sera chargé d'organiser les achats, fonction qui, jusque là, revenait à la société nationale. Ces deux mesures pourraient être prises simultanément, dans les cas où les associations d'agriculteurs disposeraient de capacités suffisantes de mettre en place et de gérer un tel mécanisme. Là où ce système existe déjà ou bien là où la société nationale achète par l'intermédiaire de négociants privés, il faudrait ensuite recourir aux appels d'offres transparents et compétitifs. À ce stade, ces systèmes ne devraient attirer que les importateurs et les distributeurs professionnels qui sont capables de mobiliser les ressources financières nécessaires et qui ont la volonté d'investir à long terme dans des activités d'importation et de distribution. L'étape finale, à savoir, le passage des systèmes de type organisations professionnelles à un système d'achat entièrement décentralisé dépendrait de la disponibilité d'un mécanisme efficace de recouvrement des créances accordées au titre de l'achat d'intrants et du degré de décentralisation de la commercialisation du coton-graine. Cette étape devient moins urgente, toutefois, si le système de type organisation professionnelle s'accompagne de procédures d'appel d'offres transparentes et compétitives.

L'objectif stratégique poursuivi doit être de maintenir le large accès aux produits de qualité qui a été l'une des principales réalisations obtenues au titre du monopole administré mais dans le cadre de systèmes d'importation et de distribution compétitifs. Outre l'élimination des barrières à l'accès, les gouvernements devront mettre en place des systèmes réglementaires appropriés pour défendre les droits contractuels, maintenir les normes de qualité, et sauvegarder la santé humaine et la sécurité de l'environnement. Le secteur privé complèterait ces initiatives par la création d'institutions de type organisation professionnelle afin de coordonner l'offre de services d'appui technique au secteur dans son ensemble et, partant, améliorer la capacité de satisfaction de la demande et d'aider les bénéficiaires à apporter leur contribution au financement de ces services. Le rôle de la Banque et des autres donateurs serait de participer au renforcement des capacités nationales de conception et de mise en œuvre de systèmes réglementaires et de soutenir des institutions de type organisation professionnelle. 


\section{Production et multiplication des semences}

On observe actuellement dans les pays d'Afrique de l'Ouest et du Centre deux structures organisationnelles dans le sous-secteur des semences. Dans la première, la société cotonnière finance le programme de recherche, contrôle le système de distribution des semences et travaille en collaboration avec des agriculteurs contractuels à la multiplication des semences améliorées. La deuxième, qui sera bientôt mise en place au Bénin, est un système privé de recherche de cofinancements, de services de vulgarisation et de sous-traitance de type organisation professionnelle en vue de la multiplication et de la distribution des semences par le canal de groupements locaux d'agriculteurs. Dans un cas comme dans l'autre, l'objectif visé doit être la création de systèmes privés efficaces de multiplication et de distribution de semences. S'agissant du premier cas, il convient d'évoluer immédiatement vers un système de type organisation professionnelle, tandis que dans le deuxième cas, la prochaine étape serait d'élargir le rôle du secteur privé tant dans la multiplication que dans la distribution des semences. Dans les deux cas, le rythme de la transition serait limité par le niveau de développement du secteur privé.

Le maintien de l'accès aux semences de haute qualité mais à travers des systèmes de multiplication et de distribution efficaces doit être l'objectif stratégique du secteur des semences. Les mesures d'accompagnement préconisées ici sont essentiellement les mêmes que dans le cas des secteurs des engrais et des pesticides. Toutefois, en plus de l'adoption et de la mise en oeuvre de systèmes réglementaires adéquats, le gouvernement devrait soutenir les systèmes nationaux de recherche et améliorer leurs résultats. Le secteur privé devra aussi mettre en place des mécanismes institutionnels qui lui permettent de participer plus efficacement à la définition des priorités en matière de recherche et d'accroître les ressources publiques limitées consacrées au financement de la recherche stratégique dans cette filière. L'assistance accordée par les donateurs contribuera à mettre en place des systèmes réglementaires nationaux et à soutenir la recherche.

\section{Politiques de prix}

Pour la campagne 2001-02, la valeur à la ferme est déjà fixée et les pouvoirs publics sont en train de mobiliser des financements additionnels afin de protéger les agriculteurs contre certaines retombées de la chute des cours mondiaux. Pour la prochaine campagne, les principes généraux suivants devraient guider les pays d'Afrique de l'Ouest et du Centre (AOC) : les mécanismes de prix adoptés pour 2002-03 ne devraient remettre en cause ni les objectifs de renforcement de la concurrence et de la privatisation ni les réformes déjà intervenues. Ainsi, au Bénin où il existe une société publique et six sociétés privées d'égrenage de coton, et là où les prix sont convenus d'un commun accord entre les sociétés d'égrenage, les producteurs et d'autres participants du marché, il convient d'éviter de revenir au prix du coton fixé par l'État.

En outre, dans les pays où un monopole d'État est maintenu, les prix payés aux producteurs doivent largement refléter les fluctuations du cours mondial comme dans un environnement compétitif caractérisé par la présence d'usines d'égrenage, ce qui est l'objectif à moyen 
terme. Les pays doivent éviter de contrecarrer l'influence des cours mondiaux notamment en s'abstenant de s'engager à maintenir les prix artificiellement élevés sur le marché intérieur alors que les cours mondiaux sont bas. Pareil comportement pourrait considérablement accroître les coûts budgétaires. Le gouvernement devrait donc strictement limiter la portée des subventions qu'ils accordent aux producteurs de coton et aux sociétés d'égrenage. Tant que les réformes n'auront pas créé un cadre propice à la concurrence entre sociétés d'égrenage, la détermination des prix (et partant la répartition du produit des ventes de coton fibre) devrait en tout état cause se faire à travers un mécanisme transparent et équitable convenu d'un commun accord entre les participants du marché (groupement de producteurs, État, sociétés d'égrenage et institutions de financement qui accordent des crédits au titre de l'achat d'intrants ainsi que des crédits de campagne). Par le passé, les sociétés d'égrenage imputaient la faiblesse des prix payés aux producteurs à l'inflation des coûts. Les sociétés d'égrenage devraient faire l'objet d'un audit et elles devraient être comparées aux sociétés qui suivent des pratiques optimales ailleurs.

Les mécanismes de détermination des prix diffèrent en fonction de l'entité qui supporte le risque de fluctuation des prix durant la moisson. On peut envisager des cas diamétralement opposés. Dans le premier cas, le prix à payer pour le coton est fixé au moment des semailles; de ce fait, le risque de fluctuation des prix entre la période des semailles et la moisson supportée par la société d'égrenage ou par l'État. Dans l'autre cas, aucun prix n'est coté aux producteurs tant que le coton n'est pas livré à l'usine d'égrenage et vendu par cette dernière. Dans ce cas, tout le risque est supporté par les producteurs, c'est-à-dire, par ceux-là même qui sont le moins à même de le faire. Dans la pratique, une variante du premier cas a été adoptée dans la plupart des pays. Toutefois, le problème qui se pose avec ce système réside dans le fait qu'il exige souvent de l'État qu'il intervienne avec des subventions, ce qui revient en effet à supporter le risque de dégradation de la situation.

Étant donné qu'il n'existe pas encore de concurrence efficace entre les sociétés d'égrenage, il serait souhaitable pour la campagne 2002-03 de mettre en place un mécanisme intermédiaire de détermination des prix qui puisse répartir une partie des risques entre les producteurs, les sociétés d'égrenage et le gouvernement. Par exemple, dans la plupart des pays où une seule société détient le monopole, et où il n'existe aucune société privée d'égrenage de coton, un tel mécanisme pourrait garantir un prix minimum aux producteurs en début de saison quitte à le compléter plus tard si les cours mondiaux demeuraient au niveau de départ ou s'ils se renchérissaient. Les sociétés d'égrenage pourraient se couvrir contre une partie de ces risques en vendant à terme mais il n'est pas possible de se couvrir totalement contre ces risques, étant donné qu'on ignore le volume de la récolte et que le coût de la protection peut parfois être prohibitif. Dans ce système, les producteurs comme les cultivateurs supportent en commun une partie des risques (ils pourraient tous voir leurs recettes augmenter lorsque les cours mondiaux se raffermissent, dans des proportions équitables et définies à l'avance). Cette pratique ne serait pas sans rappeler la ristourne que connaissent bien les cultivateurs de la région mais à une importante différence près. Le second paiement ne serait pas calculé sur la base de l'excédent enregistré par l'usine d'égrenage mais plutôt sur la différence entre le cours mondial et la valeur qui avait été prise comme hypothèse au moment de fixer le prix garanti. Cet excédent pourrait être réparti entre les cultivateurs et les usines d'égrenage selon 
le pourcentage convenu au moment de la fixation du prix garanti; l'État en profiterait aussi par le biais du relèvement des impôts sur les bénéfices des usines d'égrenage. Ces dernières seraient ainsi incitées à réduire leurs coûts étant donné qu'en le faisant, elles accroîtraient leurs bénéfices. Le mécanisme n'éliminerait pas le risque de subventions mais il le réduirait considérablement si le prix garanti était suffisamment orthodoxe.

Les efforts déployés par le passé pour réduire l'incidence des fluctuations des cours sur le revenu des producteurs par le biais des caisses de péréquation ne se sont pas couronnés de succès. Ceci s'explique en partie par le fait que les producteurs, les usines d'égrenage et l'État ne s'étaient pas clairement mis d'accord sur le régime de propriété et la maîtrise des ressources de ces caisses. Au Mali, par exemple, les producteurs estiment que les ressources de la caisse de péréquation ont été largement utilisées à la discrétion de la CMDT pour résorber des déficits imputables à la CMDT elle-même. Au Burkina Faso, en revanche, où la caisse de péréquation appartient, de toute évidence, aux producteurs qui la contrôlent, les ressources sont mieux gérées et sont à l'abri des ingérences de la société cotonnière. Par conséquent, ces ressources sont disponibles et peuvent être utilisées pour stabiliser les cours, de sorte qu'en 2001/02, les producteurs pourraient se passer des subventions de l'État.

La restructuration de la filière coton et les mécanismes de détermination des prix devraient entraîner une répartition plus équitable des recettes d'exportation entre les parties dans le cadre de négociations transparentes, et chaque partie devrait être responsable de la gestion de son propre risque de prix. Les usines d'égrenage pourraient couvrir le risque de prix au même titre que tout autre entreprise privée. Les producteurs ne sont pas bien équipés pour supporter tout seuls les risques de prix étant donné que leur épargne est généralement investie dans l'élevage dont il n'est pas facile de se désengager en cas de chute des cours du coton. Toutefois, les associations villageoises au niveau local ou national pourraient souscrire à des obligations contractuelles avec des sociétés privées d'assurances qui pourraient assurer leur revenu contre le paiement d'une prime acceptable. Ces dispositions limiteraient la nécessité d'une intervention des pouvoirs publics.

\section{E. Conclusions}

La filière coton dans les pays d'Afrique de l'Ouest et du Centre traverse actuellement une période difficile en raison des cours mondiaux qui sont tombés à des niveaux sans précédent, en partie du fait des subventions généreuses accordées aux cultivateurs de coton aux ÉtatsUnis, en Chine et au sein de l'Union européenne ainsi qu'à la transition inachevée vers un régime de concurrence entre les sociétés privées d'égrenage et les sociétés et de commercialisation du coton. Le coton est un élément clé de tout programme de réduction de la pauvreté rurale dans la région étant donné la place importante qu'il occupe dans les exportations de ces pays. Les perspectives de réduction de la pauvreté seraient considérablement améliorées si les pays industrialisés et les autres pays en développement éliminaient leurs subventions agricoles qui gonflent artificiellement l'offre et font baisser les cours mondiaux. Les pays d'Afrique de l'Ouest et du Centre (AOC) tireraient parti de la suppression du soutien des prix et des subventions octroyés aux producteurs de coton des autres régions du monde. 
Les perspectives de réduction de la pauvreté dans les pays d'Afrique de l'Ouest et du Centre (AOC) seraient améliorées sous l'effet de la réforme des filières coton afin de renforcer la concurrence et de permettre qu'une part plus importante du cours mondial soit répercutée sur les agriculteurs. Ces réformes devraient continuer d'avoir comme objectif le développement d'un secteur où l'État n'intervient plus que de manière limitée dans la détermination des prix ou l'octroi de subventions. Les usines privées d'égrenage devraient s'exposer à la concurrence en matière de détermination des prix dans le cadre d'un commun accord conclu dans un esprit d'ouverture et de transparence. Dans un tel système, les institutions seraient tenues de recouvrer les créances afin de pouvoir financer les achats d'intrants. Ainsi, il conviendra de mettre en place des associations de producteurs et des mécanismes juridiques de recouvrement des créances. Ces institutions et la concurrence entre usines privées d'égrenage ne verront, certes, pas le jour suffisamment à temps pour la prochaine campagne, mais il importe de continuer à déployer des efforts afin d'atteindre cet objectif. Dans l'intervalle, les mécanismes de prix déjà adoptés ne devraient pas remettre en cause la réalisation des objectifs de renforcement de la concurrence et de la privatisation, encore moins les réformes déjà mises en oeuvre. 
Graphique 1. Prix nominal, prix réel et stocks mondiaux de coton, janvier 1985-décembre $20021 /$

Prix rél du coton

(Franc CFA le kilo;

échelle de gauche)

Prix nominal du coton

(selon l'indice Cotlook A)

(Cents EU la livre;

echelle de droite)

Stocks mondiaux

(Millions de balles

de 480 livres;

échelle de droite)

Sources : Département d'agriculture des États-Unis; estimations des services du FMI.

1/ Stocks communiqués en août, dernier mois de la campagne de commercialisation du coton. Prix réel du coton par rapport à l'IPC de l'UEMOA, l'année de base étant 1990.

Graphique 2. Production cotonnière de la zone franc et du reste de l'Afrique subsaharienne, 1980-2001

(Milliers de tonnes métriques)

Zone franc

Reste de l'Afrique subsaharienne

Source : Comité consultatif international sur le coton.

Graphique 3. Afrique de l'Ouest et du Centre -

Ratio des coûts d'exploitation sur le total des coûts 1/

(En pourcentage)

1/ Le ratio moyen correspond au Bénin, au Burkina Faso, au Mali et

au Tchad. Les coûts d'exploitation comprennent la totalité des coûts,

exception faite du prix d'achat du coton-graine. Les conts sont fà.b. 

Policy Research Working Paper Series

Title

WPS2837 $\begin{aligned} & \text { Reform, Growth, and Poverty } \\ & \text { in Vietnam }\end{aligned}$
$\begin{aligned} & \text { WPS2838 } \begin{array}{l}\text { Economic Mobility in Vietnam } \\ \text { in the 1990s }\end{array} \\ & \text { WPS2839 Marketing Externalities and } \\ & \text { Market Development }\end{aligned}$
WPS2840 Public Spending and Outcomes:
Does Governance Matter?

WPS2841 Contractual Savings in Countries with a Small Financial Sector

WPS2842 Financial Sector Inefficiencies and the Debt Laffer Curve

WPS2843 A Practical Guide to Managing Systemic Financial Crises: A Review of Approaches Taken in Indonesia, the Republic of Korea, and Thailand

WPS2844 Money Demand in Venezuela: Multiple Cycle Extraction in a Cointegration Framework

WPS2845 The Spatial Division of Labor in Nepal

WPS2846 Is India's Economic Growth Leaving the Poor Behind?

WPS2847 The Nature and Dynamics of Poverty Determinants in Burkina Faso in the 1990s

WPS2848 Administrative Barriers to Foreign Investment in Developing Countries

WPS2849 Pooling, Savings, and Prevention: Mitigating the Risk of Old Age Poverty in Chile

WPS2850 Determinants of Commercial Bank Performance in Transition: An Application of Data Envelopment Analysis

WPS2851 Economic Development and the World Trade Organization After Doha

WPS2852 Regional Agreements and Trade in Services: Policy Issues

WPS2853 Private Interhousehold Transfers in Vietnam in the Early and Late 1990s
Author

Date

Contact

for paper

\begin{tabular}{|c|c|c|}
\hline David Dollar & May 2002 & $\begin{array}{l}\text { E. Khine } \\
37471\end{array}$ \\
\hline $\begin{array}{l}\text { Paul Glewwe } \\
\text { Phong Nguyen }\end{array}$ & May 2002 & $\begin{array}{l}\text { E. Khine } \\
37471\end{array}$ \\
\hline $\begin{array}{l}\text { M. Shahe Emran } \\
\text { Forhad Shilpi }\end{array}$ & May 2002 & $\begin{array}{l}\text { F. Shilpi } \\
87476\end{array}$ \\
\hline $\begin{array}{l}\text { Andrew Sunil Rajkumar } \\
\text { Vinaya Swaroop }\end{array}$ & May 2002 & $\begin{array}{l}\text { H. Sladovich } \\
37698\end{array}$ \\
\hline $\begin{array}{l}\text { Gregorio Impavido } \\
\text { Alberto R. Musalem } \\
\text { Dimitri Vittas }\end{array}$ & May 2002 & $\begin{array}{l}\text { P. Braxton } \\
32720\end{array}$ \\
\hline $\begin{array}{l}\text { Pierre-Richard Agénor } \\
\text { Joshua Aizenman }\end{array}$ & May 2002 & $\begin{array}{l}\text { M. Gosiengfiao } \\
33363\end{array}$ \\
\hline David Scott & May 2002 & $\begin{array}{l}\text { L. Yeargin } \\
81553\end{array}$ \\
\hline
\end{tabular}

Mario A. Cuevas

May 2002

M. Geller

85155

Marcel Fafchamps

May 2002

F. Shilpi

87476

May 2002

C. Cunanan

Gaurav Datt

Martin Ravallion

32301

May 2002

P. White

81131

May 2002

M. Feghali

36177

May 2002

T. Packard

75841

David A. Grigorian

June 2002

S. Torres

39012

June 2002

P. Flewitt

32724

June 2002

P. Flewitt

Aaditya Mattoo

32724

June 2002

E. Khine

37471 


\section{Policy Research Working Paper Series}

Title

WPS2854 Rich and Powerful? Subjective Power and Welfare in Russia

WPS2855 Financial Crises, Financial Dependence, and Industry Growth

WPS2856 Banking Policy and Macroeconomic Stability: An Exploration

WPS2857 Markups, Returns to Scale. and Productivity: A Case Study of Singapore's Manufacturing Sector

WPS2858 The State of Corporate Governance: Experience from Country Assessments

WPS2859 Ethnic and Gender Wage Disparities in Sri Lanka

WPS2860 Privatization in Competitive Sectors: The Record to Date

WPS2861 Trade-Related Technology Diffusion and the Dynamics of North-South and South-South Integration

WPS2862 Tenure, Diversity, and Commitment: Community Participation for Urban Service Provision

WPS2863 Getting Connected: Competition and Diffusion in African Mobile Telecommunications Markets

WPS2864 Telecommunications Reform in Uganda

WPS2865 Bankruptcy Around the World: Explanations of its Relative Use

WPS2866 Transforming the Old into a Foundation for the New: Lessons of the Moldova ARIA Project

\section{Author}

Michael Lokshin

Martin Ravallion

Luc Laeven

Daniela Klingebiel

Randy Kroszner

Gerard Caprio, Jr. Patrick Honohan

Hiau Looi Kee

Olivier Fremond

Mierta Capaul

Mohamed Ihsan Ajwad

Pradeep Kurukulasuriya

Sunita Kikeri

John Nellis

Maurice Schiff

Yanling Wang

Marcelo Olarreaga

Somik V. Lall

Uwe Deichmann

Mattias K. A. Lundberg

Nazmul Chaudhury

Frew Amare Gebreab

Mary M. Shirley

F. F. Tusubira

Frew Amare Gebreab

Luke Haggarty

Stijn Claessens

Leora F. Klapper

David Ellerman

Vladimir Kreacic

\section{Date}

June 2002

June 2002

June 2002

June 2002

June 2002

June 2002

June 2002

June 2002

June 2002

June 2002

June 2002

July 2002

July 2002
Contact for paper

C. Cunanan 32301

R. Vo

33722

A. Yaptenco 31823

M. Kasilag 39081

G. Gorospe 32623

Z. Jetha 84321

R. Bartolome 35703

M. Kasilag 39081

Y. D'Souza

31449

P. Sintim-Aboagye 38526

P. Sintim-Aboagye 38526

A. Yaptenco 31823

N. Jameson 30677 